\title{
WestVirginiaUniversity
}

THE RESEARCH REPOSITORY @ WVU

Graduate Theses, Dissertations, and Problem Reports

2003

\section{Dietary factors influencing iron status among WIC participants ages 6-24 months}

\author{
Marci Stayner Cannon \\ West Virginia University
}

Follow this and additional works at: https://researchrepository.wvu.edu/etd

\section{Recommended Citation}

Cannon, Marci Stayner, "Dietary factors influencing iron status among WIC participants ages 6--24 months" (2003). Graduate Theses, Dissertations, and Problem Reports. 1746.

https://researchrepository.wvu.edu/etd/1746

This Thesis is protected by copyright and/or related rights. It has been brought to you by the The Research Repository @ WVU with permission from the rights-holder(s). You are free to use this Thesis in any way that is permitted by the copyright and related rights legislation that applies to your use. For other uses you must obtain permission from the rights-holder(s) directly, unless additional rights are indicated by a Creative Commons license in the record and/ or on the work itself. This Thesis has been accepted for inclusion in WVU Graduate Theses, Dissertations, and Problem Reports collection by an authorized administrator of The Research Repository @ WVU. For more information, please contact researchrepository@mail.wvu.edu. 


\title{
DIETARY FACTORS INFLUENCING IRON STATUS AMONG WIC PARTICIPANTS AGES 6-24 MONTHS
}

\author{
Marci Stayner Cannon
}

Thesis submitted to

College of Agriculture, Forestry, and Consumer Sciences

at

West Virginia University in partial fulfillment of the requirements

For the degree of

\author{
Master of Science \\ In \\ Human Nutrition and Foods \\ Cindy Fitch, Ph.D, RD, Chair \\ Debra Krummel, Ph.D., RD \\ Monica Andis, MS, RD
}

Division of Family and Consumer Sciences

\section{Morgantown, West Virginia 2003}

Keywords: iron deficiency, infants and toddlers, iron status, serum ferritin, diet, WIC

Copyright 2003 Marci Stayner Cannon 


\begin{abstract}
Dietary Factors Influencing Iron Status Among WIC Participants 6-24 Months

Marci Stayner Cannon

Iron deficiency is a nationwide concern. Dietary strategies issued by national organizations, aim to help prevent childhood iron deficiency. This study examined the relationship of dietary factors with iron status in WIC participants 6-24 months. This was a cross-sectional study of 50 rural infants and toddlers.

Iron deficiency was determined from one blood sample analyzed for serum ferritin (SF) and transferrin saturation (TS). Iron deficiency was defined as SF $\leq 15$ $\mathrm{ug} / \mathrm{dL}$ and TS $\leq 15 \%$. Two, 24-hour dietary recalls were collected. Stepwise logistic regression was used to evaluate factors predictive of iron status.

Thirteen children $(26 \%)$ were iron deficient. Iron status could be predicted from iron-fortified infant or adult cereal intake $(p=0.04)$. Mean SF tended to be lower in those consuming $>24$ ounces of milk per day $(p=0.07)$. On regression analysis, meat, fish, or poultry intake was positively $(p=0.018)$ and calcium intake was negatively $(p=0.0004)$ associated with SF.
\end{abstract}




\section{ACKNOWLEDGEMENTS}

I would like to express sincere appreciation to Dr. Cindy Fitch, advisor and chair of this thesis committee. I would like to thank her for her patience, guidance, and knowledge she has shared with me. In addition, I wish to acknowledge Dr. Debra Krummel for her patience, knowledge in methodology and data analysis and assistance through the process. I would like to thank Monica Andis for the knowledge she has shared with me, patience as I learn new skills and her enthusiasm for learning. I appreciate all the time that she is always willing to spend to give me assistance anytime that I have needed it.

I would also like to thank George Seidel for his assistance with the statistical analysis and his patience in answering questions.

To my husband, Jonathan Cannon, for his patience, understanding and love. He encouraged me on and supported me in my toughest days.

To my parents, Dick and Marla Stayner, for supporting me in continuing my education even when it meant leaving my home of Salt Lake City, Utah. I also thank them for supporting me in all of my ambitions and goals. Thank you to my parents for their countless sacrifices in my behalf. 


\section{TABLE OF CONTENTS}

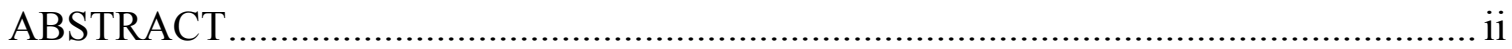

ACKNOWLEDGEMENTS ............................................................................... ii

LIST OF TABLES ......................................................................................... vii

CHAPTER 1: INTRODUCTION ....................................................................... 1

CHAPTER 2: LITERATURE REVIEW .......................................................... 4

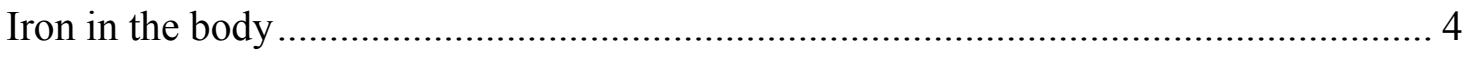

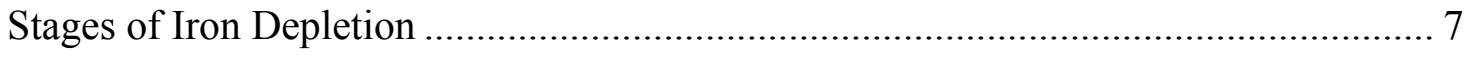

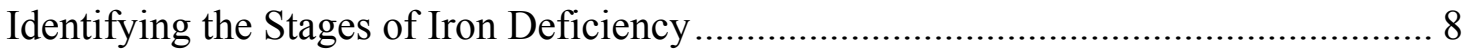

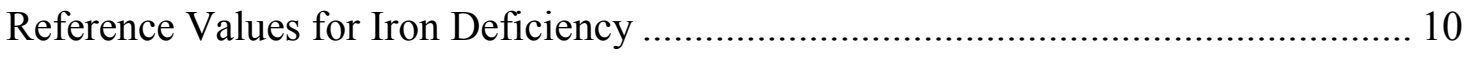

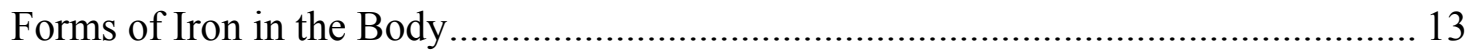

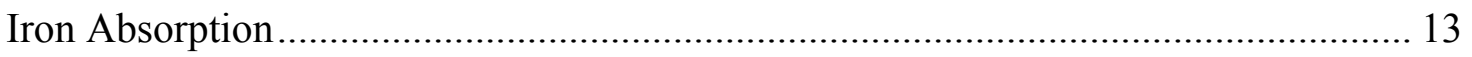

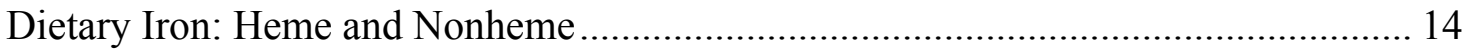

Heme Iron Absorption ................................................................................. 14

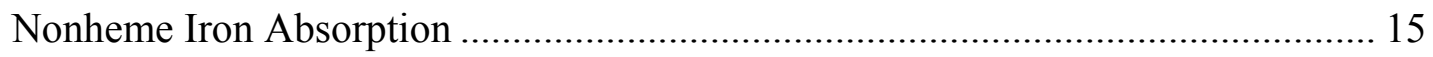

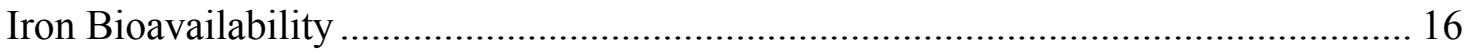

Summary of factors that influence the absorption of iron ..................................... 17

Dietary iron intake and iron absorption ........................................................ 18

Dietary calcium intake and iron absorption ................................................... 19

Dietary vitamin C, iron intake and iron absorption ...................................... 20

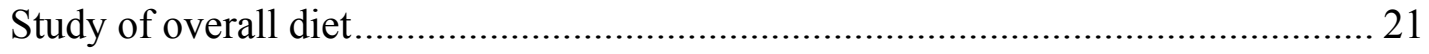

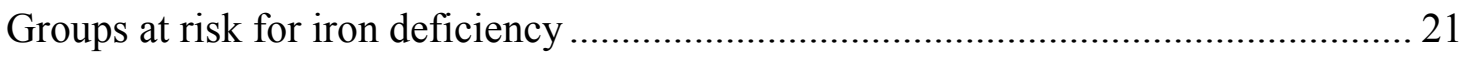

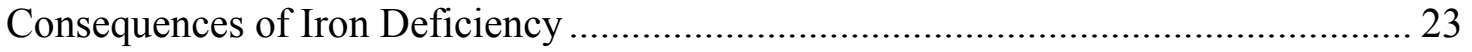




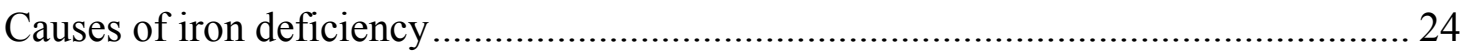

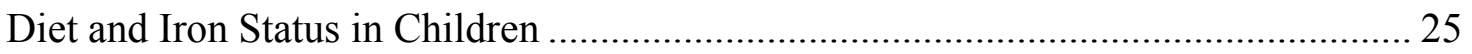

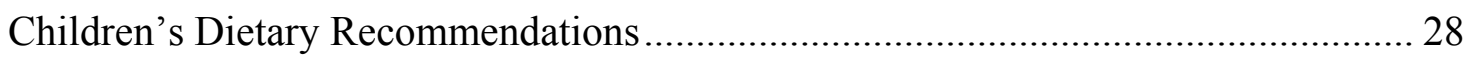

Rationale for the Study ……………................................................................. 29

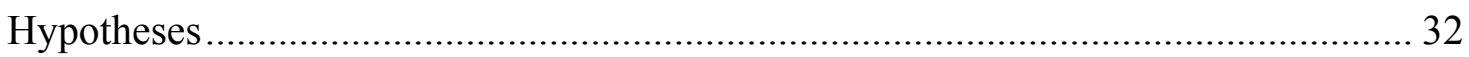

Hypotheses: Dietary Intake Between 6-12 Month and 13-24 Month olds ............... 32

Hypotheses: Iron Status and Dietary Factors......................................................... 33

Hypotheses: Serum Ferritin and Dietary Factors.................................................... 34

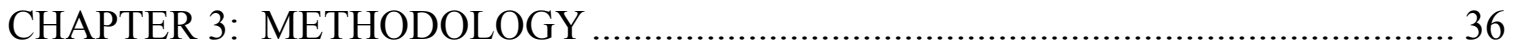

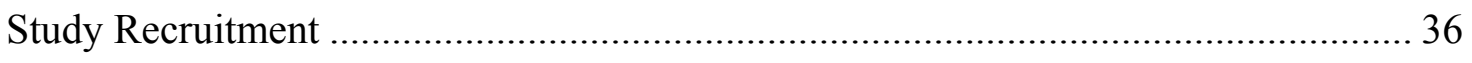

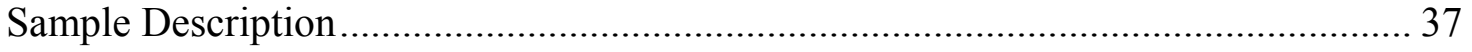

Appointment with Research Assistant ........................................................................ 37

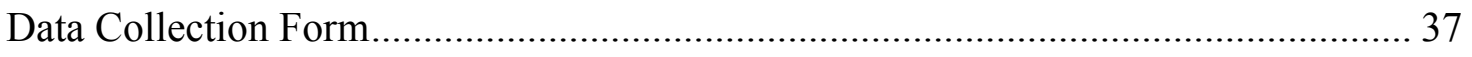

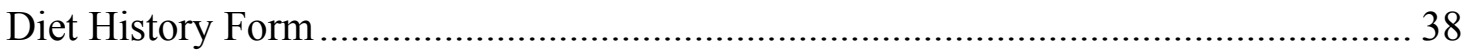

Dietary Assessment- Multiple Pass 24-hour Dietary Recall.......................................... 38

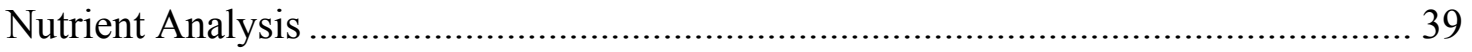

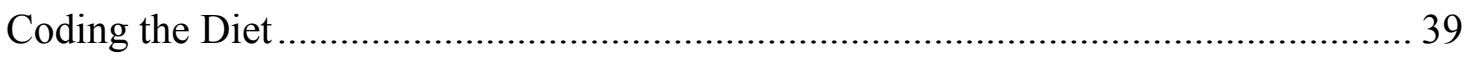

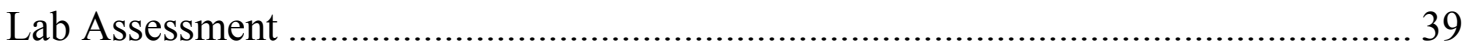

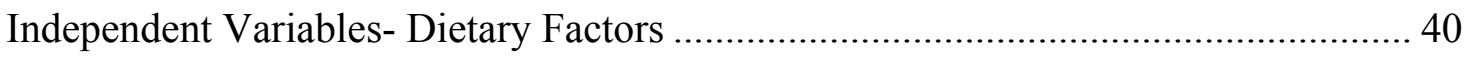

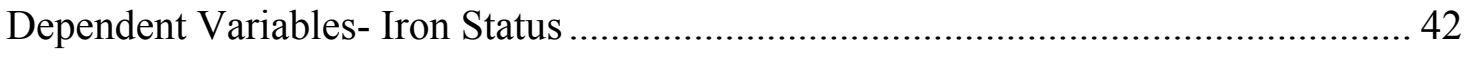

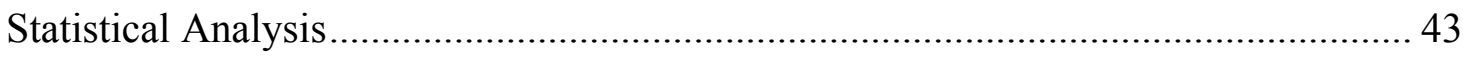

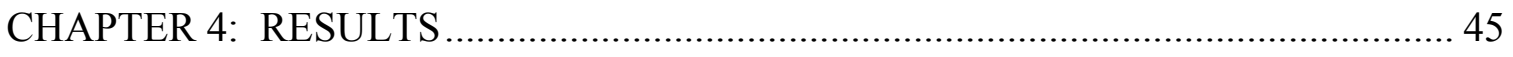

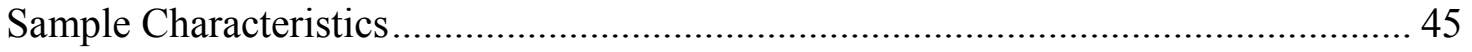




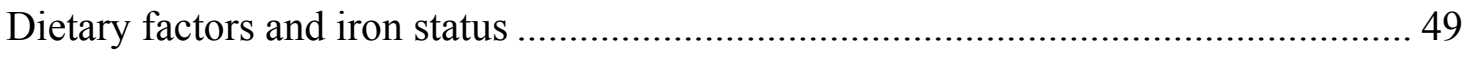

Dietary factors and serum ferritin ................................................................... 50

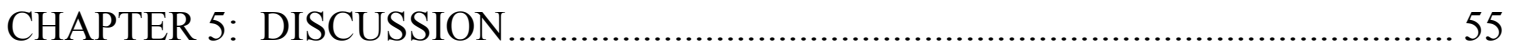

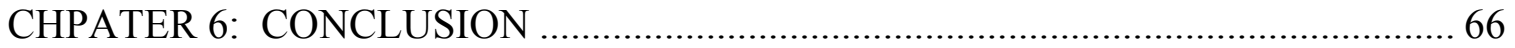

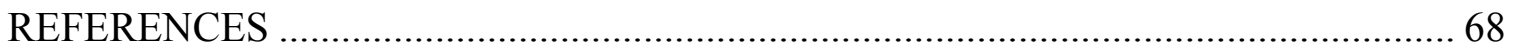

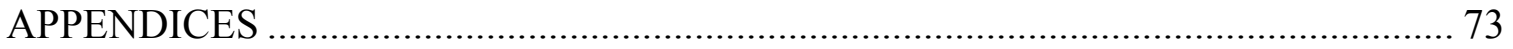

APPENDIX A Data Collection Form ……......................................................... 74

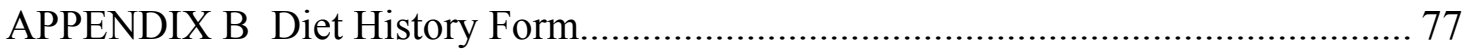

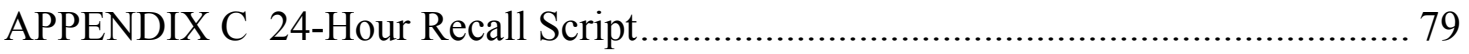

APPENDIX D Individual Intake Form ............................................................ 83

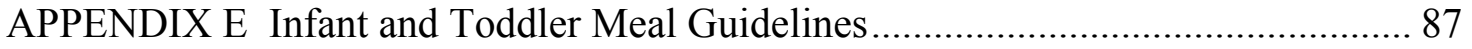

APPENDIX F Common Foods Consumed.......................................................... 90

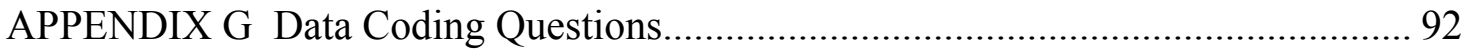

APPENDIX H Prevention Recommendations...................................................... 94

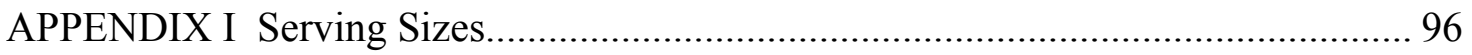

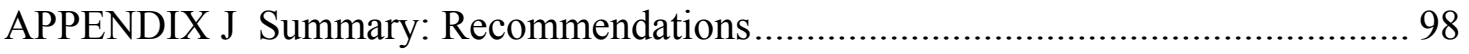

APPENDIX K Summary: Nutrient Intake ...................................................... 100

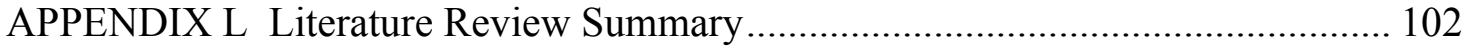

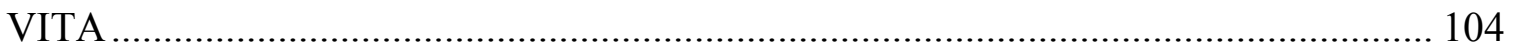




\section{LIST OF TABLES}

$\begin{array}{lll}\text { TABLE 1: } & \text { Iron status and stages of iron deficiency }\end{array}$

TABLE 2: $\quad$ Dietary Reference Intake for children 7 months to $3 \quad 29$ years of age

TABLE 3: Characteristics of sample 45

TABLE 4: $\quad$ Number of children by age group and dietary 46 factors

TABLE 5: $\quad$ Nutrient intake by age $\quad 47$

TABLE 6: $\quad$ Iron status by age group $\quad 48$

TABLE 7A: Average serum ferritin and dietary factors for all $\quad 51$ children

TABLE 7B: Average serum ferritin and dietary factors for 6-12 51 month olds

TABLE 7C: Average serum ferritin and dietary factors for 13-24 51 month olds

TABLE 8A: Simple Linear Regression 2 day average nutrient 53 intake and serum ferritin for all children

TABLE 8B: Simple Linear Regression 2 day average nutrient 53 intake and serum ferritin for 6-12 month olds

TABLE 8C: Simple Linear Regression 2 day average nutrient 53 intake and serum ferritin for 13-24 month olds

TABLE 9: Pearson correlations of average nutrient intake and iron status indicators 


\section{CHAPTER 1}

\section{INTRODUCTION}

Iron deficiency is the most common nutritional deficiency worldwide (USDHHS, 1998). The World Health Organization considers iron deficiency to be the number one nutritional disorder in the world with a prevalence of more than $30 \%$ of the world's population (Washington DC, International Life Science Institute, 1998). Infants, young children, and women of childbearing years are among the groups most vulnerable to iron deficiency. Iron deficiency is of particular concern among young children because of its long lasting affects. If left to persist, iron deficiency causes developmental delays and behavioral disturbances that are irreversible even upon iron repletion (USDHHS, 1998).

Infants and young children ages 9-18 months are the age group at the highest risk of any age group for iron deficiency. They frequently have an inadequate intake of dietary iron concurrent with rapid growth and an extra need for iron (Miller and Baehner, 1995). Of particular concern are young children that are members of low-income families. The Centers for Disease Control and Prevention (CDC) reports that the prevalence of iron deficiency is higher among children living at or below the poverty level than it is among those living above the poverty level (USDHHS, 1998). During infancy and early childhood, children undergo a rapid rate of growth. Iron stores of fullterm infants can meet an infant's iron requirements until the age of 4-6 months. At about 9 months, neonatal iron stores can become depleted if appropriate dietary practices are

not followed. As the infant ages, the diet begins to broaden and increase in variety. By 12 months, the diet changes from a breast milk or formula-based, iron-rich diet to a diet of solid foods that are often poor in iron. 
An inadequate intake of dietary iron is not the only risk factor for iron deficiency among infants and children. Poor absorption of available dietary iron, diet composition, and current iron status also contribute to the bioavailability of dietary iron and should also be taken into account. Researchers are beginning to investigate the effects of dietary factors on iron status in children, but studies to date have not clearly and consistently shown the significance of dietary factors on iron status. This information could help provide caregivers with more dietary information to help prevent the occurrence of iron deficiency among young children.

Is childhood iron deficiency a preventable deficiency? The successes demonstrated by the efforts of the WIC (Special Supplemental Nutrition Program for Women, Infants, and Children) program in identifying and providing assistance to children presenting with iron deficiency seem to show that it may be preventable to a large extent. This program was initiated in the early 1970s to provide supplemental food and nutrition education to low-income families with children or pregnant mothers. As a result of the efforts of this and many other programs, the prevalence of iron deficiency in children less than two years old fell from 14\% to 3\% between 1975 and 1985 (Miller et al., 1985). More recently, the results of the NHANES III (third National Health and Nutrition Examination Survey 1988-1994) showed that the prevalence of iron deficiency among children under the age of 3 years was 9\% (Looker, 1997; Eden, 1997). When the data were separated for one year old and two year old children, the prevalence of iron deficiency was $13 \%$ in one year old children and 5\% in two year old children.

Great strides have been made in preventing iron deficiency but iron deficiency among young children still exists. Because of the long lasting effects of iron deficiency 
on children, it should be prevented in every child. CDC reports that primary prevention of iron deficiency through dietary practices is an important factor for children less than two years of age (USDHHS, 1998). To address these recommendations, this study will examine the following questions. Does the daily consumption of an iron-fortified cereal intake influence iron status? Does the daily consumption of meat, fish or poultry influence iron status? Does the intake of a fruit, vegetable or juice with a meal influence iron status? Does daily consumption of cow's milk greater than 24 ounces per day influence iron status? Does daily multivitamin intake influence iron status? Do nutrients known to enhance (dietary iron and vitamin C) or inhibit (calcium) iron absorption influence iron status? $\mathrm{CDC}$ and other agencies have recognized the problem of iron deficiency among young children and have issued dietary recommendations to help prevent iron deficiency. Are children's diets reflecting these recommendations? By following these recommendations can iron deficiency be prevented in young children? This study seeks to answer these questions. 


\section{CHAPTER 2}

\section{LITERATURE REVIEW}

Anemia is the most familiar consequence of iron deficiency. The terms iron deficiency, anemia, iron-deficiency anemia and iron depletion are often used interchangeably, but are not equivalent (USDHHS, 2000). Iron deficiency includes a range of short-term depleted iron stores that are not harmful, to long-term iron deficiency that affect the functioning of body organ systems. Long-term iron deficiency is referred to as anemia. Anemia is more likely than iron deficiency without anemia to cause adverse effects such as delays in infant and child development (USDHHS, 2000; Lee et al., 1993).

Iron in the body

Iron is an essential mineral in the body. It plays a critical role in transporting oxygen from the lungs to the body's tissues as a component of hemoglobin in red blood cells, and myoglobin in the muscles.

Iron is incorporated into the body in several compartments. Sixty-seven percent of the body's iron is contained in the heme groups of hemoglobin and is involved in oxygen transport (Miller and Baehener, 1995). Three percent is involved in oxygen storage as myoglobin and thirty percent is deposited in stores as ferritin or hemosiderin. Only trace amounts of iron are present in the blood plasma attached to transferrin $(0.07 \%)$ and in tissues as heme enzymes (0.2\%) (Tilkian, Conover, and Tilkian, 1995). Once full growth is achieved, the body's iron remains fixed within narrow limits. Iron rarely leaves the body, but instead is recycled through several functional pools. 
The metabolism of iron is dominated by its role in hemoglobin synthesis. Iron is used repeatedly; therefore, the movement of iron is described as a cycle. In this cycle, iron travels from blood plasma to the bone marrow, where it is incorporated into hemoglobin. It is then released with the mature red blood cells into the circulation. After a life span of about 120 days, mature red blood cells are destroyed and then recycled. The iron from the hemoglobin is extracted and returned to the plasma where it is bound to transferrin, an iron transport protein (Tilkian et al., 1995).

The body does not lose substantial amounts of iron from the body except with blood loss such as during menstruation and childbearing. Minimal losses occur through shedding of epithelial cells from the skin, gut, and urinary tract. These iron losses are balanced by absorption of iron from the diet. An adequate amount of iron must be supplied in the diet to help maintain iron homeostasis.

Iron stores are well maintained in the body (Miller and Baehner, 1995). Body iron stores exist in two forms, ferritin and hemosiderin. Most of the storage iron is in cells of the liver, spleen, lymph nodes, and bone marrow (Mazza, 2002). Storage iron is also present in myoglobin cells in the skeletal and cardiac muscle cells. Iron is also part of enzymes, chytochromes and myoglobin (Mazza, 2002). Storage iron provides iron to the body when iron is not available through other sources.

Ferritin, a form of iron storage, is soluble and readily available for storage (Miller and Baehner, 1995). Ferritin molecules have a central core of iron atoms. Iron enters and leaves the structure through six channels, which penetrate the protein shell. When fully saturated, ferritin contains about 4500 iron atoms per molecule. Ferritin molecules are located in the liver and the heart. When the body's iron is depleted, ferritin does not 
acquire iron, instead it allows the newly acquired iron to be used for metabolic and synthetic needs. With iron repletion, ferritin synthesis is reinitiated and excess iron is diverted to temporary stores.

When ferritin stores are saturated, hemosiderin is formed (Miller and Baehner, 1995). Hemosiderin iron is a large complex of protein and iron and is more stable and less available than ferritin iron. Its iron content is variable, but it is considerably greater in iron content than ferritin. Iron enters and leaves this storage compartment by way of ferritin. Ferritin is converted to hemosiderin and appears to be influenced by the tissue density of iron. The relative amount of hemosiderin rises as tissue iron content rises. It is only with sustained negative or positive balances that the hemosiderin pool changes in size. Hemosiderin is deposited primarily in the cells of the liver, spleen, and bone marrow.

Bone marrow utilizes iron from iron stores and gastrointestinal absorption to produce new red blood cells. The needed iron is transported in the blood from storage sites by a blood protein called transferrin which can bind two atoms of $\mathrm{Fe}^{+3}$ iron (Mazza, 2002). The concentration of transferrin present in the blood plasma is determined by the rate of transferrin synthesis which is governed by the ferritin content of the liver cells (Miller and Baehner, 1995). Transferrin production is increased in iron deficiency and decreased in states of iron overload. The blood plasma concentration of transferrin is measured as the total iron binding capacity (TIBC). It provides a convenient marker of iron stores. Transferrin receptor levels are increased in iron deficiency (Miller and Baehner, 1995). Blood transferrin receptor levels do not increase until iron stores are 
depleted. This suggests that the measurement of serum transferrin receptor may be useful in identifying iron deficiency of early onset.

\section{$\underline{\text { Stages of Iron Depletion }}$}

Table 1. Serum iron status and stages of iron deficiency (Miller and Baehner, 1995)

\begin{tabular}{|c|c|c|c|c|}
\hline & Normal & $\frac{\text { Storage Iron }}{\text { Deficiency }}$ & $\begin{array}{l}\text { Iron-Limited } \\
\text { Erythropoiesis }\end{array}$ & $\frac{\text { Iron-deficiency }}{\underline{\text { anemia }}}$ \\
\hline & $\begin{array}{ll}\text { Storage } & X \\
\text { RBC Iron } & X\end{array}$ & $\begin{array}{ll}\text { Storage } & \text { / } \\
\text { RBC Iron } & X\end{array}$ & $\begin{array}{ll}\text { Storage } & \mathrm{O} \\
\text { RBC Iron } & \mathrm{X}\end{array}$ & $\begin{array}{ll}\text { Storage } & \mathrm{O} \\
\text { RBC Iron } & /\end{array}$ \\
\hline $\begin{array}{l}\text { Hemoglobin } \\
\text { (gm/dl) }\end{array}$ & 12 & 12 & 12 & $<11$ \\
\hline $\begin{array}{l}\text { Transferrin } \\
\text { Saturation (\%) }\end{array}$ & 22 & 22 & $<10$ & $<10$ \\
\hline $\begin{array}{l}\text { FEP (Free } \\
\text { Erythrocyte Porphyrin) } \\
\text { (ug/dl RBC) }\end{array}$ & 30 & 30 & $>100$ & $>100$ \\
\hline $\begin{array}{l}\text { Ferritin } \\
\text { (ug/l) }\end{array}$ & 30 & $<12$ & $<12$ & $<12$ \\
\hline
\end{tabular}

$\mathrm{X}=$ Full

/ =Partially Full

$\mathrm{O}=$ Empty

Iron deficiency occurs in stages. Iron-deficiency anemia is the end result of a series of steps that begins with depletion of stored body iron (Lee et al., 1993). When the absorption of iron is insufficient to meet the body's iron requirement, iron stores begin to be utilized. Iron requirements are determined by growth rates and iron losses (Miller and Baehner, 1995).

The first stage of iron depletion is termed storage iron deficiency. In this stage, iron stores are decreased or depleted, but do not manifest an effect on essential body iron. This stage is characterized by low serum ferritin levels (See Table 1). Red blood cell iron is still sufficient. Hemoglobin, transferrin saturation, free erythrocyte porphyrin, blood iron concentration, and mean corpuscular volume (MCV) remain normal (Mazza, 2002). While there are no apparent adverse consequences at this stage of iron depletion, it does 
represent a condition of vulnerability (Dallman, 1990). The body tries to compensate for iron loss and attempts to prevent further losses by increasing absorption of dietary iron in the gut.

The second stage of iron depletion is termed iron-limited erythropoiesis (See Table 1) In this stage, storage iron is completely depleted and iron is not available to be incorporated into the hemoglobin molecule of red blood cells or other essential iron compounds (Dallman, 1990). Hemoglobin continues to remain within normal limits, but tranferrin saturation, serum ferritin, and free erythrocyte prophyrin become abnormal. This stage is identified clinically by a low blood transferrin saturation level, a low serum ferritin and an elevated free erythrocyte protoporphyrin level. Serum transferrin receptors have been found to increase during this stage.

The third stage of iron depletion is termed iron-deficiency anemia (See Table 1). At this stage, there is an insufficient flow of iron to the bone marrow site for hemoglobin production. This causes a decrease in blood hemoglobin concentration (Miller and Baehner, 1995). Often mean corpuscular volume (MCV) is also below normal (Dallman, 1990; Lee et al., 1993). A diagnosis of anemia is made if there is a low blood hemoglobin or hematocrit concentration accompanied by another blood lab abnormality, such as low serum ferritin (Dallman, 1990). At this stage abnormalities in physiological and neurological functions can occur.

\section{Identifying the Stages of Iron Deficiency}

The stages of iron deficiency progression can be identified by using serum iron laboratory tests. Each test assesses a different aspect of iron status. A combination of 
two or more abnormal iron status lab results are used to diagnose iron deficiency (USDHHS, 1998).

Hemoglobin concentration and hematocrit are the most frequently used values for evaluating iron status. They are easy to collect and inexpensive to evaluate. These measures reflect functional iron in the body. Hemoglobin is the oxygen carrying protein in red blood cells. The hemoglobin concentration level reveals how much hemoglobin is present in a person's blood. A normal hemoglobin reading for children is $>12 \mathrm{~g} / \mathrm{dl}$. Hematocrit is a measure of the proportion of whole blood occupied by red blood cells. In iron deficiency the hematocrit falls only after hemoglobin concentration falls. Both hemoglobin concentration and hematocrit lab results change at late stages of iron deficiency and are therefore not good indicators of early iron deficiency.

Serum ferritin concentration is directly related to the amount of stored iron (Tilkian et al., 1995). It accurately reflects body stores and is an early indicator of iron stores. It is the most specific indicator available of depleted iron stores, especially when used in conjunction with other tests to assess iron status (USDHHS, 1998). For example, when hemoglobin presents as low, a low serum ferritin would confirm the anemia due to iron deficiency. Nearly all ferritin in the body is intracellular, only a small amount circulates in the plasma. Under normal conditions, a direct relationship exists between serum ferritin concentration and the amount of iron stored in the body, such that $1 \mathrm{ug} / \mathrm{L}$ of serum ferritin concentration is equivalent to approximately $10 \mathrm{mg}$ of stored iron. Serum ferritin concnetraion is especially useful because it is not affected by day-to-day fluctuations in iron intake (Australian Iron Status Board). In children ages 6-24 months, 
$\mathrm{CDC}$ reports that the average serum ferritin concentration is approximately $30 \mathrm{ug} / \mathrm{L}$ (USDHHS, 1998).

Transferrin saturation is secondary indicator of iron deficiency. It cannot be used as a sole indicator for iron deficiency. Transferrin saturation indicates the extent to which transferrin, the serum iron carrying protein, has vacant iron-binding sites (e.g., low transferrin saturation indicates a high proportion of vacant iron-binding sites).

Transferrin saturation is based on two laboratory measures, serum iron concentration and total iron-binding capacity (TIBC). TIBC reflects the availability of iron-binding sites on transferrin. Transferrin saturation is calculated by dividing serum iron concentration by TIBC and multiplying by 100 to express the result as a percentage: (USDHHS, 1998) Transferrin saturation $(\%)=($ serum iron concentration $\mathrm{ug} / \mathrm{dL} / \mathrm{TIBC} \mathrm{ug} / \mathrm{dL}) \mathrm{X} 100$ Reference Values for Iron Deficiency

Numerous studies have been done to evaluate iron deficiency in children ages 624 months old. Reference values and serum iron tests selected for identifying iron deficiency vary from study to study.

The World Health Organization (WHO) identifies iron status as: (Kapur, Agarwal and Agarwal, 2002).

- Iron Deficiency - Serum Ferritin $\quad<12 \mathrm{ug} / \mathrm{dL}$

- Mild Anemia- Hemoglobin 10.0-10.9 g/dl

- Moderate Anemia - Hemoglobin 7.0-9.9g/dl

- Severe Anemia - Hemoglobin $\quad<7.0 \mathrm{~g} / \mathrm{dl}$ 
The Centers for Disease Control and Prevention (CDC) identifies iron status as:

(USDHHS, 1998).

- Hemoglobin

$<11.0 \mathrm{~g} / \mathrm{dL}$

(cutoff for anemia)

- Hematocrit

$<32.9 \%$

(cutoff for anemia)

- Mean Cell Volume

$<77 \mathrm{fL}$

(cutoff for microcytic anemia)

- Red Blood Cell Distribution

$14.0 \%$

(cutoff for iron-deficiency anemia)

- Erythrocyte Protoporphyrin Concentration $80 \mathrm{ug} / \mathrm{dL}$ (cutoff for children 1-2 years)

- Serum Ferritin Concentration $\leq 15 \mathrm{ug} / \mathrm{L}$ (cutoff for iron deficiency >6months)

- Transferrin Concentration $\leq 15 \%$ (cutoff for iron deficiency)

The American Academy of Family Physicians identifies iron status as: (Kazal, 2002)

- Iron Depletion:

Serum Ferritin $<10 \mathrm{ug} / \mathrm{L}-1$

- $\quad \downarrow$ Iron Transport:

Transferrin Saturation $<10 \%$

- $\quad \downarrow$ Hemoglobin Production:

Erythrocyte protoporphyrin $\geq 35 \mathrm{ug} / \mathrm{dL}$ High RDW

MCV ( $<70$ um3 a late finding)

Hemoglobin $<11 \mathrm{~g} / \mathrm{dL}$ or $<110 \mathrm{~g} / \mathrm{L}$

In a study by Gibson (1999), examining the association of iron status with breakfast cereals, vitamin $\mathrm{C}$ and meat for children 1.5-4.5 years old, iron status was identified as:

- Low Iron Stores

Serum Ferritin $<10 \mathrm{ug} / \mathrm{dL}$ 
- Anemia

In a study by Thane et al. (2000), examining the risk factors of poor iron status in British children 1.5-4.5 years old, children were divided into categories according to iron status indicators:

- Hemoglobin

$$
\begin{aligned}
& <110 \mathrm{~g} / \mathrm{L} \\
& <120 \mathrm{~g} / \mathrm{L}
\end{aligned}
$$

- Ferritin

$$
\begin{aligned}
& <10 \mathrm{ug} / \mathrm{dL} \\
& <12 \mathrm{ug} / \mathrm{dL}
\end{aligned}
$$

- Both Hemoglobin and Ferritin

$<110 \mathrm{~g} / \mathrm{L}$ and $<10 \mathrm{ug} / \mathrm{dL}$

In a study by Oti-Boateng et al. (1998), assessing the association of iron status and dietary iron intake of 6-24 month old children, iron status was identified as:

- Iron Sufficient

$\begin{array}{ll}\text { Hemoglobin } & >110 \mathrm{~g} / \mathrm{L} \\ \text { Serum Ferritin } & \geq 15 \mathrm{ug} / \mathrm{dL} \\ \text { Transferrin Level } & >3.0 \mathrm{~g} / \mathrm{L} \\ \text { Serum Iron } & \geq 8 \mathrm{umol} / \mathrm{L} \\ \text { Iron Saturation } & \geq 12 \%\end{array}$

- Non-Anemic Iron Deficieny

$\begin{array}{ll}\text { Hemoglobin } & >110 \mathrm{~g} / \mathrm{L} \\ \text { Serum Ferritin } & <15 \mathrm{ug} / \mathrm{dL} \\ \text { Transferrin Level } & >3.0 \mathrm{~g} / \mathrm{L} \\ \text { Serum Iron } & <8 \mathrm{umol} / \mathrm{L} \\ \text { Iron Saturation } & >12 \%\end{array}$

- Iron-Deficiency Anemia

Hemoglobin

Serum Ferritin

Transferrin Level

Serum Iron

Iron Saturation
$<110 \mathrm{~g} / \mathrm{L}$

$<15 \mathrm{ug} / \mathrm{dL}$

$>3.0 \mathrm{~g} / \mathrm{L}$

$<8 \mathrm{umol} / \mathrm{L}$

$<12 \%$ 
In a study by Soh et al. (2002), examining dietary factors associated with serum ferritin levels in children 6-24 months, iron status was identified as:

$$
\text { - Adequate Iron Status Serum Ferritin } \geq 20 \mathrm{ug} / \mathrm{dL}
$$

Forms of Iron in the Body

Iron exists in several states varying from $\mathrm{Fe}^{+6}$ to $\mathrm{Fe}^{-2}$ (Groff, Gropper, and Hunt, 1995). Iron in the body circulates in two valent states, $\left(\mathrm{Fe}^{+3}\right)$ ferric form and $\left(\mathrm{Fe}^{+2}\right)$ ferrous form. They are the only stable forms of iron found in the human body and in food. In the body, iron must be absorbed in the ferrous $\left(\mathrm{Fe}^{+2}\right)$ form. The ferric form is reduced to ferrous in the presence of hydrochloric acid and reducing agents such as ascorbic acid. (Allen and Ahluwalia, 1997).

\section{$\underline{\text { Iron Absorption }}$}

Iron absorption is the amount of dietary iron that the body obtains from food. The absorption of iron from food is influenced by the form and content of iron, the presence of inhibitors and enhancers and host factors including current body iron status. Heme iron is absorbed much more readily in the body than nonheme iron. A major determinant of the absorption of nonheme iron in the small intestine is its' solubility. Nonheme iron solubility is aided or hindered by iron enhancers or inhibitors (Allen and Ahluwalia, 1997).

Actual absorption of iron can vary from $1 \%$ to more than $50 \%$ depending on the combination of these factors (Lee et al., 1993; Tilkian et al., 1995; Groff et al., 1995; Hallberg, Brune and Rossander, 1989; Guthrie, 1996). The body adapts to absorb more iron when more is needed. When body iron stores become depleted, iron absorption increases (Hallberg et al., 1989). A healthy person absorbs about 15\% of dietary iron 
(Tilkian et al., 1995). Iron absorption can be as high as 35-50\% in an iron deficient person (Groff et al., 1995).

There are two pathways for iron absorption in the body (Lee et al., 1993; Tilkian et al., 1995). Iron can be absorbed as iron attached to heme, or as iron in the ferrous state $\left(\mathrm{Fe}^{+2}\right)$

\section{Dietary Iron: Heme and Nonheme}

There are two forms of dietary iron: heme and nonheme (Groff et al., 1995). Heme iron is part of hemoglobin and myoglobin and is found in animal products such as meat, fish, seafood, and poultry. Nonheme iron is found primarily in plants. Food sources of nonheme iron include leafy greens (broccoli, kale, turnip greens, collards) and dry beans and peas (lima beans, green peas, pinto beans, black-eyed peas and canned beans). In addition, many foods are now fortified with nonheme iron. Flours, cereals, and grain products that are enriched or fortified with iron are good dietary sources of nonheme iron.

\section{Heme Iron Absorption}

Heme iron from meat, poultry and fish is readily absorbed. Heme is freed from the globin portion of the hemoglobin molecule when it is exposed to the acid and gastric juices of the stomach (Groff et al., 1995). Iron contained in the heme is then oxidized to the ferric state, forming hemin. The heme that contains the iron and the porphyrin ring is then absorbed intact (as a metalloporphyrin) into the mucosal cell of the small intestine. Within the mucosal cell the absorbed heme is broken down by a heme oxygenase into ferrous iron and protoporphyrin. The released iron moves through the mucosal cells for 
use by the intestinal cell or for transport and use by other body tissues. Heme iron absorption is not extensively influenced by enhancers and inhibitors.

\section{$\underline{\text { Nonheme Iron Absorption }}$}

Nonheme iron is much less readily absorbed by the gastrointestinal tract than heme iron. Nonheme iron is usually bound to components of foods and must be hydrolyzed or solubilized before it can be absorbed (Groff et al., 1995). Although heme iron is absorbed together with its ferric component, nonheme iron must be in the ferrous state for absorption to occur (Tilkian et al., 1995; Mazza, 2002). Ferric iron can be reduced to the ferrous form in the presence of hydrochloric acid that is present in gastric juice (Groff et al., 1995).

During digestion, nonheme iron can change its valence state and rapidly form iron-chelate complexes with dietary components such as ascorbic acid, phytate, tannins, and oxalate. The strength of the iron-chelate bond, the solubility of the complex, and environmental factors such as $\mathrm{pH}$ and the presence of other competing chelators, determine whether iron is available for uptake by mucosal cells (Allen and Ahluwalia, 1997).

In the stomach, most iron is released from the iron complexes in food (aided by the acidic $\mathrm{pH}$ and digestive processes) and enters the common nonheme iron pool. Here, in the presence of reducing agents such as ascorbic acid, 75 to 98 percent of the ferric iron is reduced to the ferrous form. The entry of iron into the common iron pool is limited by their solubility (Allen and Ahluwalia, 1997).

The common pool of ferrous and ferric iron, and dietary components such as phytate, tannins, ascorbate, oxalate, leaves the stomach and enters the intestine where the 
$\mathrm{pH}$ is about 7 or 9 (Allen and Ahluwalia, 1997). At this point there is competition between the different dietary components to form complexes with iron. Iron bioavailability is determined by the degree of the affinity of each dietary component for iron and the solubility of the iron-dietary component complex. The strength of the bond with which the dietary component complexes with iron contributes to either enhancement or inhibition of iron absorption. Enhancers of iron absorption bind iron securely and are soluble in the gastrointestinal tract. Thus, enhancers are those dietary components that form soluble chelates with iron (especially ferric iron) and prevent its precipitation, allowing the release of iron for absorption by the mucosal cell. Vitamin $\mathrm{C}$, amino acids, heme iron and citric acid are examples of enhancers. Inhibitors are those dietary factors that chelate iron to form insoluble complexes or complexes of very high affinity, so that iron is not released from the chelate for absorption. Examples include tannins, phytate, and oxalates (Allen and Ahluwalia, 1997).

Iron Bioavailability

Bioavailability is defined as the amount of a nutrient biologically available for absorption (Gurthrie, 1996; Oski, 1993). It takes into consideration factors such as absorbability of the form of iron and the effects of other dietary factors on absorption. Many factors affect the bioavailability of iron in the diet.

One major factor affecting the bioavaliability of iron, is the form of iron consumed (Guthrie, 1996). Dietary iron is divided into two major categories: heme and nonheme iron. Heme iron comprises $40 \%$ of the iron in meat, poultry, and fish, the remainder being nonheme iron. The iron in dairy and plant foods is nonheme iron, which provides over $60 \%$ of total dietary iron. 
Although heme iron makes up a smaller part of the iron in the food supply, it is more readily absorbed than nonheme iron and heme iron's absorption is not impaired by most inhibitory factors. Nonheme iron absorption, however, is affected by a number of dietary inhibitors and enhancers. Nonheme iron absorption can vary as much as tenfold (Lee et al., 1993). Dietary enhancers of nonheme iron include vitamin C, heme iron, and citric, malic, lactic, tartaric, and other organic acids. Vitamin $\mathrm{C}$ influences nonheme iron absorption by reducing ferric iron $\left(\mathrm{Fe}^{+3}\right)$ to the absorbable ferrous form $\left(\mathrm{Fe}^{+2}\right)$.

Certain ingredients in foods inhibit nonheme iron absorption. Phytates, natural components of grains and some vegetable foods, legumes and nuts, form poorly absorbable complexes with iron (Lee et al., 1993). Bran and other fibers inhibit iron absorption mainly because of their phytate content. Soy protein, coffee, phosphoprotein in eggs and polyphenols found in tea, vegetables, legumes, and red wine have also been noted as inhibitors of nonheme iron absorption. High intakes of zinc and calcium may also interfere with iron absorption (Hallberg, 1983; Lee et al., 1993; Oski, 1993). Calcium has been found to inhibit both heme and nonheme iron absorption. Consuming calcium as part of a meal or with multivitamin-mineral supplements has been reported to inhibit the absorption of iron ingested by as much as 50\% (Guthrie, 1996).

$\underline{\text { Summary of factors that influence the absorption of iron }}$

NONHEME IRON (Guthrie, 1996)

Substances that inhibit nonheme iron absorption

Phytates

Plant polyphenolics

High dietary amounts of zinc

Soy Protein

Egg

Coffee and tea

Bran 


\section{Substances that enhance nonheme iron absorption}

\section{Ascorbic acid}

Meat, poultry, and fish

Citric, malic, lactic, tartaric, and other organic acids

Fermentation products of soybeans

Low iron content of meals

Iron in Ferrous form

\section{HEME AND NONHEME IRON}

Substances that inhibit heme and nonheme iron absorption

Calcium

\section{Substances that enhance heme and nonheme iron absorption}

Low iron stores of individuals

The effects of a low vitamin A status have also been researched in connection with iron deficiency. Vitamin A acts to help mobilize iron from its storage sites. A deficiency of vitamin A limits the body's ability to use stored iron. Even though the body can maintain normal amounts of stored iron, iron deficiency may be diagnosed based on a laboratory reading of low hemoglobin level. This is uncommon in the U.S., but is a problem is seen in developing countries where vitamin A deficiency often occurs (Washington DC, International Life Sciences Institute, 1998).

Dietary iron intake and iron absorption

Many studies have examined the absorption of dietary iron in the diet. Hunt, and Roughead (2000), compared the absorption of nonheme iron and heme iron in 31 men. They found that the men adapted by absorbing more nonheme iron when they were iron deficient but adaptation did not occur with heme iron absorption. They concluded that nonheme iron absorption is increased in an iron deficient state whereas heme iron is not as well absorbed in an iron deficient state. 
In another study conducted by Engelmann et al. (1998), the absorption of non heme iron in infants was investigated. They fed infants baby food meats with a puree vegetable meal naturally containing nonheme iron. They found that nonheme iron absorption increased with the addition of meat, containing heme iron.

These studies suggest, that in an iron deficient person, nonheme iron is absorbed more readily while heme iron absorption is relatively unaffected. In addition, the intake of heme iron helps the absorption of nonheme iron.

\section{Dietary calcium intake and iron absorption}

Dietary calcium is known to have inhibitory effects on the absorption of iron. Gleerup et al. (1995) investigated the possibility of reducing calcium inhibition of iron absorption by decreasing calcium intake in lunch and dinner meals, the meals which provided the most dietary iron. They examined 21 healthy female volunteers ages 21-44 years old. Most subjects were senior students in the nutrition program or staff members at the Department of Internal Medicine, University of Goteborg, Annedalsklinikerna, Sahlgren's Hospital, Goteborg, Sweden. Meals were labeled with two different iron radioisotopes and equivalent amounts of calcium $(937 \mathrm{mg}$ ) were distributed either in breakfast and late evening meals or more uniformly in all meals. Then iron absorption from two identical 10 day periods wee compared. The results of this study showed that $30-50 \%$ more iron was absorbed when no milk or cheese was served with lunch or dinner. The results were statistically significant. The researchers suggested that a separation of calcium and iron intakes during mealtime would improve iron nutrition.

Ames et al. (1999) investigated the effects of a high and low calcium diet on calcium absorption and incorporation of iron into red blood cells of children ages 3-5 
years old. The sample consisted of eleven children ages 3-5 years of age from the greater Houston metropolitan area. Menus were selected to provide approximately the current recommended amount of iron in the diet. The children's calcium intake was increased by providing menus with additional calcium from dairy sources. Calcium supplements were not permitted. To maintain a relatively constant iron intake while increasing calcium intake, subjects were counseled to increase their intake of meat and iron-fortified cereal. Low calcium diet contained 502/mg calcium per day while the high calcium diet contained $1180 \mathrm{mg}$ per day. Baseline blood samples were obtained for measurement of hemoglobin and serum ferritin. At the end of the low and high calcium diet intervention, incorporation of iron into red blood cells and calcium absorption were measured. Their results were opposite of what the researchers hypothesized. The results of the study revealed that the absorption of iron was higher with the higher calcium diet. In this study, an increase in dietary calcium did not have a statistically significant effect on iron absorption.

The results of these studies were not consistent with regards to the extent of the inhibitory effects of calcium on iron absorption. Further research is needed to clarify the effects of calcium on iron absorption.

Dietary vitamin $\mathrm{C}$, iron intake and iron absorption

Ascorbic acid and iron are related. Ascorbate reduces the ferric ion (fe $3+)$ form of iron to the ferrous ion $(\mathrm{Fe} \mathrm{2+})$ form (Lee et al., 1993). Ascorbate is required to release iron from the storage state (Tilkian et al., 1995). Ascorbic acid (vitamin C) plays a key role in the absorption of dietary nonheme iron. It acts in two ways. First, it prevents the formation of insoluble and unabsorbable iron compounds. Second, it assists in the 
reduction of ferric to ferrous iron, which seems to be a requirement for the uptake of iron into the mucosal cells (Hallberg et al., 1987). The iron absorption enhancing effects of the vitamin $\mathrm{C}$ are dose related. With higher the doses of vitamin $\mathrm{C}$, more iron is absorbed in the gut.

Lynch and Cook (1980) have described the effects of vitamin C as an iron absorption enhancer. They stated that vitamin $\mathrm{C}$ can reverse the iron absorption inhibiting effects of such substances as tea and calcium/phosphate. This may not be as apparent in meals containing heme iron, which is readily available. They also stated that the enhancement of iron absorption from nonheme iron meals is directly proportional to the quantity of ascorbic acid present in the meal.

\section{$\underline{\text { Study of overall diet }}$}

Overall diet can also have an affect on iron-deficiency anemia. Boutry and Needlman (1996) hypothesized that a poor diet, defined as a diet low in meats, grains, fruit, and vegetables and high in dairy products, sweets, fatty snacks, and soft drinks, would be associated with iron deficiency. In this study, they found that a nutrient poor diet in children lead to low blood iron status.

\section{$\underline{\text { Groups at risk for iron deficiency }}$}

Despite continued efforts to prevent iron deficiency among children and infants in the United States, the incidence of iron deficiency among children and infants is declining only gradually. NHANES III survey (Third National Health and Nutrition Examination Survey 1988-1994) showed that the prevalence of iron deficiency among children under the age of 3 years was 9\% (Looker, Dallman, Carroll, Gunter and Johnson, 1997; Eden and Mir, 1997). A third of those children were identified as anemic, 
describing a condition that occurs beyond iron deficiency. When the data were separated for one year old and two year olds, the prevalence of iron deficiency was 13\% in one year old and 5\% in two year olds. A significant number of children in the United States still present with iron deficiency, especially among one to two year old children.

Unfortunately, the risk of iron deficiency is greater among children that come from families living at or below the poverty level (Looker et al., 1997). Each year, the Centers for Disease control and Prevention (CDC) monitors the prevalence of anemia in low-income infants and children using the Pediatric Nutrition Surveillance system (PedNSS) (West Virginia Department of Health and Human Resources Bureau for Public health, 1997). In West Virginia, all PedNSS data come from WIC clinics, a low income population. In 1998, the overall prevalence of anemia among WIC children in West Virginia was 6.5\%. However, in eleven West Virginia counties the anemia rate was greater than $10 \%$ of WIC children with anemia. The target for reduction in iron deficiency for Healthy People 2010 is $5 \%$ of the population of children ages one to two years. Children who are served by the WIC program in WV are not yet meeting the target.

Infancy and early childhood are critical periods for adequate dietary iron intake. At these stages, iron intake is essential to accommodate for the rapid rate of growth and the great increase in red blood cell mass (Dallman, 1990). In healthy full-term infants, iron stores are adequate until age four to six months. Iron requirements may exceed dietary iron intake after this time. Iron deficiency is often more common in populations with low incomes. The Maternal and Child Health Bureau states that infants and children from low-income families, children who are eligible for WIC, children from migrant 
families and children that are recently arrived refugees are at high risk for iron deficiency (Story, Holt and Denise, 2002). They recommend that these children should be screened for iron deficiency at age 9-12 months. It is recommended that beyond these ages they should be screened annually from ages 2-5 years of age (Story et al., 2002).

\section{Consequences of Iron Deficiency}

Infancy is a critical period for brain growth. Nutrient deficiencies during this period may affect psychomotor development and neurocognition (Couper, 2001). Iron deficiency develops gradually over a period of time. Symptoms are often not noticed as the body adapts to the decreasing amount of iron available for the production of heme in the hemoglobin in red blood cells. Many negative effects have been shown in children that are iron deficient. Iron deficiency impairs the growth in infancy and childhood. In one study, 78 of 156 iron-deficient children fell below the twenty-fifth percentile of expected weight. Growth rate was restored once iron stores were adequate (Lee et al., 1993).

A variety of behavioral disturbances have been observed in iron-deficient children (Lee et al., 1993). Studies indicate that iron-deficient children were irritable, disruptive, had short attention spans, and lacked interest in their surroundings. Neurological development in infants and scholastic performance in older children were impaired (Mazza, 2002). Dallman noted, after a review of several studies, that iron-deficient children had impaired psychomotor development, impaired intellectual performance and changes in behavior (Dallman, 1990). These developmental skills were evaluated for children and infants 6 months through 2 years of age using the Bayley Scale of Infant Development, a developmental test that evaluates sensory development, fine and gross 
motor skills, and language development. Using this test, infants who were even mildly iron deficient were found to exhibit a statistically significant decrease in responsiveness and activity, and an increase of body tension, fearfulness, and tendency to fatigue.

Although some of the abnormalities that can occur as an end result of anemia can be improved with iron therapy, some developmental abnormalities cannot be reversed. In five studies from four cultures reviewed by Oski (1993) there was a significant association of iron deficiency with changes in behavioral development. In each study an improvement in iron status of the children did not produce an improvement in the Bayley Scale of Infant Development test scores. These results suggest that iron deficiency at a critical period of brain growth and differentiation may produce some irreversible abnormalities.

The manifestations of iron deficiency are usually subtle. Children become more functionally impaired as their iron stores become increasingly depleted (Dallman, 1990). Other negative effects of iron deficiency in addition to growth retardation and developmental delays include lower resistance to infection, decreased ability to regulate body temperature, and decreased energy metabolism and work performance (Looker et al., 1997; Freire, 1997; Haroon and Pettifor, 2001; Walter, De Andraca, Chadud, and Perales, 1989).

\section{Causes of iron deficiency}

Among infants and toddlers, there are three age groups that are at risk for iron deficiency. The problem is different in each group. In early infancy (0-6 months), iron stores are heavily influenced by what has occurred in pregnancy. Iron deficiency at this stage usually occurs as a result of low birth iron stores in premature and low birth weight 
infants. Extra iron given in the diet during this period for these children is beneficial and can prevent further problems with iron deficiency. In full term infants, birth iron stores remain until four to six months. Infants may become vulnerable at this stage to iron deficiency due to poor feeding practices. Breast milk or an iron-fortified infant formula are necessary to retain iron stores. The use of low-iron infant formulas and exclusive breastfeeding without introduction of iron-fortified infant cereals and later baby foods can contribute to iron deficiency in late infancy.

After the first birthday, the range and variety of foods is broadened and eating patterns are beginning to be established. Energy and iron demands for growth are high. Psychological and neurological development is rapidly occurring. Although the causes of iron deficiency among toddlers continue to be studied, Hurrell (1997) reported that irondeficiency anemia in toddlers ages 1-2 years in the United States and other developed countries most often results from poor dietary habits formed in late infancy and early childhood. The dietary patterns from late infancy that lead to iron deficiency in early childhood include prolonged exclusive breast feeding, delayed introduction of solids and overdependence on cow's milk. Toddlers also tend to be picky eaters and may prefer high calorie snack foods lacking in adequate iron (Boutry and Needleman, 1996). Dietary patterns in late infancy and early childhood are important in preventing iron deficiency. Diet and Iron Status in Children

Investigations of the causes of iron deficiency among children have been conducted worldwide and have examined all socioeconomic classes. Studies have been conducted in Britain, Australia, South Africa, India, Ireland and the United States. These studies have shown that dietary risk factors for childhood iron deficiency include over- 
dependence on cow's milk and dairy products, low heme iron intake (from meat, fish or poultry), low total iron intake, and low consumption of fruits, vegetables, meats and cereals (Thane, Walmsley, Bates, Prentice, and Cole, 2000; Cowin, Emond, and Emmett, 2001; Oti-Boateng, Seshadri, Petrick, Gibson, and Simmer, 1998; Soh, Ferguson, McKenzie, Skeaff, Parnell, and Gibson, 2002; Gibson, 1999; Mira, Alperstein, Karr, Ranmuthugala, Causer, Niec, and Lilburne, 1996). Although the above studies have found dietary factors that influence iron status, dietary factor influences vary in significance from study to study. Differences may be accounted for by examining the methods used to collect dietary information and serum iron indicator cut points used to determine iron deficiency. Further investigations are needed to further determine the influences of dietary factors on iron status.

In Mainland Britain, researchers (Thane et al., 2000) examined the factors influencing poor iron status in 1675 children ages 1.5-4.5 years. The children were part of the National Diet and Nutrition Survey (NDNS) in Britain, 1992-1993. The results of the study showed that iron status was directly associated with meat and fruit consumption and inversely associated with milk and milk products. Few associations were observed between poor iron status and individual nutrient intakes. Iron status was not associated with either iron intake or with the consumption of a vegetarian diet.

In another study of British children age 18 months, investigators (Cowin et al., 2001) found that higher levels of milk and dairy products were associated with lower ferritin levels (body storage iron). They also found that hemoglobin levels were positively associated with vitamin $\mathrm{C}$ intake and were higher in children who ate any fruit 
or any vegetables. A low hemoglobin was more prevalent in children who consumed no meat or poultry.

In a study conducted in Adelaide Australia among 234 healthy children ages 6-24 months, iron deficiency was positively associated with cow's milk intake (Oti-Boateng et al., 1998). A study of children 6-24 months in urban South Island New Zealand, showed that iron and vitamin $\mathrm{C}$ intake were associated positively with serum ferritin, while intakes of calcium and dietary fiber were negatively associated (Soh et al., 2002).

In another study analyzing the data from the United Kingdom National Diet and Nutrition Survey (NDNS) of children aged 1.5-4.5 years, it was found that children who consumed a high amount of cereal had higher iron intakes but not significantly higher ferritin levels. The high cereal consumers also had a low vitamin $\mathrm{C}$ and meat consumption which may have diluted the impact of the iron from cereal on iron status. Children with a high intake of two of the following (vitamin C, meat, and breakfast cereals) had higher mean hemoglobin levels than those with low intakes of all three of these dietary factors. The researchers concluded that rich sources of iron should be emphasized to improve iron status. In addition, factors that may enhance or inhibit absorption should also be emphasized such as vitamin $\mathrm{C}$ and iron-fortified breakfast cereals (Gibson, 1999).

A study comparing the nutrient intake of iron depleted children aged 12-36 months with controls matched for age and sex showed that the average daily intake of heme iron was significantly lower in the iron-depleted group. There was also a tendency towards a lower average daily intake of nonheme iron and vitamin $\mathrm{C}$ for the iron depleted children. Low intake of heme iron was significantly associated with iron depletion. The 
researchers concluded that low heme iron intake is a major risk factor for iron deficiency (Mira et al., 1996).

Collectively, these studies support that over-dependence on cow's milk and dairy products, low intake of vitamin $\mathrm{C}$, heme and nonheme iron have an negative effect on iron status. On the other hand, a moderate consumption of fruits, vegetables, cereals and meats have a positive effect on iron status.

A few studies have shown that dietary factors do not have a significant effect on children's iron status. A study conducted in Madrid, Spain of a sample of 302 children ages 6 months- 15 years showed that nutritional intake did not have a significant relationship with iron status indicating that in healthy children, abnormal biochemical iron status parameters may be related to factors other than nutritional intake (FernandezBallart et al., 1992). Another study conducted in England of a sample of 4-40 month old children, showed no association between iron status and dietary intake of iron. There was also no association between protein, energy, nutritional status, and iron status (Duggan et al., 1991). In another study, individuals studied had a dietary heme-iron intake lower than recommended. Researchers found no relationship between the level of serum ferritin and total iron and vitamin $\mathrm{C}$ dietary intake, although they did find a positive correlation between serum ferritin and intake of heme iron (Spodaryk, 1999).

\section{Children's Dietary Recommendations}

Below are the Dietary Reference Intake (DRI's) for the nutrients of investigation in this study (Institute of Medicine, 1998). 
Table 2. Dietary Reference Intake for children 7 months to 3 years of age

\begin{tabular}{|l|l|l|}
\hline & $7-12 \mathrm{Months}$ & $1-3$ Years \\
\hline Iron & $11 \mathrm{mg} /$ day & $7 \mathrm{mg} /$ day \\
\hline Vitamin C & $50 \mathrm{mg} /$ day & $15 \mathrm{mg} /$ day \\
\hline Calcium & $270 \mathrm{mg} /$ day & $500 \mathrm{mg} /$ day \\
\hline
\end{tabular}

\section{$\underline{\text { Rationale for the Study }}$}

Continued efforts to prevent iron deficiency in early childhood through dietary changes are needed, especially in high risk populations such as children at or below the poverty level. Iron supplementation, fortification of foods and infant formulas have played a major role in the efforts towards decreasing the incidence of iron deficiency among infants and children. Other changes such as increased emphasis on breastfeeding and delaying the introduction of cow's milk until twelve months old have also played a significant role (Kleinman, 1998).

In the past decades, severe iron-deficiency anemia has been declining in the United States, but mild iron deficiency still persists. Because of the known damaging long-term consequences of iron deficiency, iron deficiency should be prevented in every child (Oski, 1993). Continued efforts toward the prevention of iron deficiency during the second year of life should be pursued (Eden and Mir, 1997).

In the early 1970 's, iron deficiency affected $30 \%$ to $75 \%$ of children one to two years of age who attended public health clinics. In 1974, the WIC program (Special Supplemental Food Program for Women, Infants, and Children) was initiated (Owen and Owen, 1997; Oliveira and Gundersen, 2001; Miller, Swaney, and Deinard, 1985). As a result of the efforts of this and many other programs, the prevalence of iron deficiency in children less than two years old fell from 14\% to 3\% between 1975 and 1985 (Miller and Baehner, 1995). The Healthy People 2010 initiative, a federal program coordinated by 
the Office of Disease Prevention and Health Promotion, U.S. Department of Health and Human Services, is also currently making efforts to reduce iron deficiency among children (US DHHS, 2000). The overall goal of this federal initiative is to improve the overall health of Americans. In the Healthy People 2000 publication, the prevalence of iron deficiency among American children ages 1-2 years of age was determined as 9\%. Iron status among children has been readdressed in the Healthy People 2010 initiative. The objective for 2010 is to reduce the prevalence of iron deficiency among children 1-2 years of age from $9 \%(1988-1994)$ to $5 \%$. CDC also notes that infants and toddlers from low income families are at a greater risk of iron deficiency (USDHHS, 1998).

Iron deficiency has been recognized by several governmental agencies as a continuing problem. In response to the need to prevent iron deficiency among infants and children, these agencies have issue recommendations to prevent iron deficiency. CDC states that "primary prevention of iron deficiency in infants and preschool children should be achieved through the diet" (USDHHS, 1998). Specific recommendations for children 6-24 months include: (USDHHS, 1998).

- Encourage breast feeding of infants,

- When exclusive breast feeding is stopped, encourage use of an additional source of iron (approximately $1 \mathrm{mg} / \mathrm{kg}$ per day of iron), preferably from supplementary foods.

- For infants aged less than 12 months who are not breast fed or who are partially breast fed, recommend only iron-fortified infant formula as a substitute for breast milk.

- For breast-fed infants who receive insufficient iron from supplementary foods by age 6 months (i.e., less than $1 \mathrm{mg} / \mathrm{kg}$ per day), suggest $1 \mathrm{mg} / \mathrm{kg}$ per day of iron drops.

- For breast-fed infants who were preterm or had a low birth weight, recommend 2$4 \mathrm{mg} / \mathrm{kg}$ per day of iron drops (to a maximum of $15 \mathrm{mg} /$ day) starting at $1 \mathrm{month}$ after birth and continuing until 12 months after birth. 
- Encourage use of only breast milk or iron-fortified infant formula for any milkbased part of the diet (e.g., in infant cereal) and discourage use of low-iron milks (e.g., cow's milk, goat's milk, and soy milk) until age 12 months.

- Suggest that children aged 1-5 years consume no more than 24 oz of cow's milk, goat's milk, or soy milk each day.

Solid Foods

- At age 4-6 months or when the extrusion reflex disappears, recommend that infants be introduced to plain, iron-fortified infant cereal. Two or more servings per day of iron-fortified infant cereal can meet an infant's requirement for iron at this age.

- By approximately age 6 months, encourage one feeding per day of foods rich in vitamin C (e.g., fruits, vegetables, or juice) to improve iron absorption, preferably with meals.

- Suggest introducing plain, pureed meats after age 6 months or when the infant is developmentally ready to consume such food.

The American Academy of Family Physicians dietary recommendations for preventing iron deficiency in the second year of life include (Kazal, 2002):

- Consumption of a diversified diet that is rich in sources of iron and vitamin C

- Limiting cow's milk consumption to less than 24 oz per day

- Continuing the use of cereals fortified with iron instead of more advertised cereals

- Avoiding excessive juice intake

- Providing a daily iron-fortified vitamin.

Bright Futures in Practice publications were initiated in 1990 guided by the Health Resources and Services Administration' Maternal and Child Health Bureau (Story et al., 2002). These publications include comprehensive guidelines for health professionals to provide care to American children. These guidelines are supported by such professional organizations as the American Academy of Pediatrics, American 
Dietetic Association, and Association of Maternal and Child Health Programs. Dietary guidelines within this publication for improving iron status include:

- An increased consumption of lean meat, fish, and poultry, which contain heme, and are an effectively absorbed form of iron from hemoglobin and myoglobin

- Include sources of vitamin C (e.g., citrus and fortified fruit juices, citrus fruit, strawberries, cantaloupe, green peppers, broccoli, cabbage) with meals to increase the absorption of non-meat sources of iron by maintaining the iron in its reduced, more soluble form.

- Consume highly fortified breakfast cereals that can improve iron intake.

- Liver is not recommended because of its high cholesterol content and potentially high level of environmental toxins.

Many agencies are aware of the problem of iron deficiency among American children and are issuing dietary recommendations to reduce the incidence of iron deficiency. The aim of this study is to determine the children in this population that are following the dietary recommendations (Kazal, 2002; Story et al., 2002; USDHHS, 1998) issued to help prevent iron deficiency. In addition, this study examines the relationship between iron status of WIC participants, ages 6-24 months, and dietary factors. Dietary factors selected to examine were chosen based the dietary recommendations issued by the CDC, Bright Futures and American Academy of Family Physicians with special emphasis on CDC recommendations.

\section{$\underline{\text { Hypotheses }}$}

Hypotheses: Dietary Intake Between 6-12 Month and 13-24 Month olds

1. There is no difference in consumption of 1 age-appropriate serving size of ironfortified adult or infant cereal per day between the 6-12 month and 13-24 month olds. 
2. There is no difference in consumption age-appropriate serving size of meat, fish or poultry per day between the 6-12 month and 13-24 month olds.

3. There is no difference in consumption of 1 age-appropriate serving size a fruit, vegetable or juice with one meal during the day between the 6-12 month and 1324 month olds.

4. There is no difference in consumption of cow's milk greater than 24 ounces per day between the 6-12 month and 13-24 month olds.

5. There is no difference in intake of a daily multivitamin between the 6-12 month and 13-24 month olds.

6. There is no difference in dietary iron intake between the 6-12 month and 13-24 month olds.

7. There is no difference in dietary vitamin $\mathrm{C}$ intake between the 6-12 month and 1324 month olds.

8. There is no difference in dietary calcium intake between the 6-12 month and 1324 month olds.

\section{Hypotheses: Iron Status and Dietary Factors}

9. There is no difference in iron status of children 6-24 months of age who consume 1 age-appropriate serving size of an iron-fortified adult or infant cereal per day compared to those who don't.

10. There is no difference in iron status of children 6-24 months of age who consume 1 age-appropriate serving size of meat, fish or poultry per day compared to those who don't. 
11. There is no difference in iron status of children 6-24 months of age who consume 1 age-appropriate serving size a fruit, vegetable or juice with one meal during the day compared to those who don't.

12. There is no difference in iron status of children 6-24 months old who consume greater than 24 ounces/day of cow's milk per day compared to those who don't.

13. There is no difference in iron status of children 6-24 months old who consume a daily multivitamin compared to those who don't.

14. There is no difference in iron status of children 6-24 months old with dietary iron intake.

15. There is no difference in iron status of children 6-24 months old with dietary vitamin C intake.

16. There is no difference in iron status of children 6-24 months old with dietary calcium intake.

Hypotheses: Serum Ferritin and Dietary Factors

17. There is no difference in serum ferritin of children 6-24 months of age who consume 1 age-appropriate serving size of an iron-fortified adult or infant cereal per day compared to those who don't.

18. There is no difference in serum ferritin of children 6-24 months of age who consume 1 age-appropriate serving size of meat, fish or poultry per day compared to those who don't.

19. There is no difference in serum ferritin of children 6-24 months of age who consume 1 age-appropriate serving size a fruit, vegetable or juice with one meal during the day compared to those who don't. 
20. There is no difference in serum ferritin of children 6-24 months old who consume greater than 24 ounces/day of cow's milk per day compared to those who don't.

21. There is no difference in serum ferritin of children 6-24 months old who consume a daily multivitamin compared to those who don't.

22. There is no difference in serum ferritin of children 6-24 months old with dietary iron intake.

23. There is no difference in serum ferritin of children 6-24 months old with dietary vitamin $\mathrm{C}$ intake.

24. There is no difference in serum ferritin of children 6-24 months old with dietary calcium intake.

The findings of this study will add to the current research examining the influences of dietary factors on iron status and will help to demonstrate whether or not the children that are following current dietary guidelines to prevent iron deficiency among WIC participants 6-24 months. 


\section{CHAPTER 3}

\section{METHODOLOGY}

\section{$\underline{\text { Study Recruitment }}$}

A cross-sectional study design was used. Participants were healthy children ages 6-24 months of age who were recruited from eight West Virginia county Special Supplemental Nutrition Program for Women, Infant, and Children) (WIC) clinics ( $\mathrm{n}=$ 50). Counties were selected according to the data from the Pediatric Nutrition Surveillance System (PedNSS) which revealed the counties with an anemia prevalence rate of $10 \%$ or greater among WIC children ages $0-5$ years (West Virginia Department of Health and Human Resources Bureau for Public Health, 1997). The PedNSS monitors the prevalence of specific health indicators of nutrition risk in low-income infants, children and adolescents. The Centers for Disease Control and Prevention (CDC) have been collecting PedNSS data since 1973. West Virginia counties included were Gilmer, Mason, Calhoun, Ritchie, Jackson, Pleasants, Braxton, and Greenbrier. Income eligibility for participation in the WIC program is $<185 \%$ of the federal poverty level, therefore, study participants were members of low-income families. Data was collected from July 2001 to December 2002.

The WIC Nutritionists informed parents of eligible children about the study during their regular WIC appointment. Interested parents were given a stamped addressed postcard to mail to the study coordinator. Upon receiving the postcard, a research assistant called and arranged a time to meet the parents at the WIC clinic. Parents, of children included in the study, were compensated for their time with a $\$ 40$ check after they had completed the appointment with the research assistant. 
Parents provided written consent for their children to participate in the study. This study was reviewed and approved by the West Virginia University Institutional Review Board for the protection of Human Subjects

\section{Sample Description}

Seventy-five children ages 6-24 months enrolled in the study. Parents of children recruited for the study that did not complete the study were given $\$ 10.00$ for their time. Fifty children $(66 \%)(6-12$ months $n=18,13-24$ months $n=32)$ were included in the analysis described in this paper. To be included in the study, two days of 24-hour recalls had to be completed for the child and a serum ferritin level obtained. Children were not considered for the study if they had an infection at the time of the blood draw or disease (diabetes, kidney disease, cancer, heart disease, liver disease).

Appointment with Research Assistant

During the appointment, the research assistant obtained the child's height and weight, performed a multiple pass 24-hour dietary recall for the child's diet and gave the caregiver instructions of where to obtain a blood draw. The caregiver also provided information about the child's medical history and dietary patterns. The information was recorded on the Data Collection Form and Diet History Form (Appendix A and B). Within one week, an additional 24-hour dietary recall using the same multiple pass method to obtain the diet recall was obtained over the telephone.

\section{$\underline{\text { Data Collection Form }}$}

Information collected on the Data Collection Form (See Appendix A) included date of birth, gender, weight, length, length of gestation, birth weight and length, history of chronic illness (asthma, disability, constipation, vomiting), diseases (diabetes, kidney 
disease, cancer, heart disease, liver disease), how long ago their child last had (cough, diarrhea, ear infection, bacterial infection requiring antibiotic), allergies, food intolerances, medications, surgeries, and existing nutritional deficiencies.

\section{Diet History Form}

Information collected on the Diet History Form (See Appendix B) included age, weight, appetite, past two weeks illnesses (vomiting, diarrhea, constipation), vitamin or mineral supplement, type of water, how you feed your baby (bottle, feeder, cup, spoon), if they put cereal or other foods in the baby's bottle, if they had given baby food directly from a jar, how they were feeding their baby when they left the hospital (bottle, breast, both), if they are breastfeeding now, how many weeks they breastfed before they stopped and why they stopped, if their child drinks cow's milk, how many glasses of cow's milk the child drinks each day, if the mother was participating in WIC before or while she was pregnant, and if the mother took prenatal vitamins.

\section{Dietary Assessment- Multiple Pass 24-hour Dietary Recall}

The research assistant followed a written script for a multiple pass 24-hour diet recall (See Appendix C and D) to obtain the dietary recall for each child. In the first pass, the interviewer obtained a list of foods eaten by the child from the mother in the previous day. The second pass, identified the time each food was eaten and identified the occasion (breakfast, lunch, dinner, snack) of eating each food item. The third pass, identified the amount of food eaten. Household measuring utensils were used to determine portion sizes. Within one week following the set appointment another 24-hour diet recall was obtained over the phone by the research assistant using the same multiple pass script. 


\section{Nutrient Analysis}

The two 24-hour diet recalls were analyzed for each participant. The 24-hour dietary recalls were entered into Food Processor VII, a computerized dietary analysis program, by a research assistant. Nutrient analysis reflects an average of the two-day intake. Quantitative intake for all nutrients were calculated and compared to current intake recommendations as issued by the National Academy of Science, Institute of Medicine.

\section{Coding the Diet}

Each dietary factor was coded individually from the 2 days of 24-hour recalls. When the child's diet met the individual dietary factor criteria it was coded as meeting the criteria and visa versa. In some instances the dietary recalls did not have mealtimes recorded. Information about consuming a fruit, vegetable or juice with a meal was not able to be obtain. When data was missing the entire observations was omitted from the particular analysis where these factors were used. Questions used to code data from the dietary recalls can be found in appendix G.

\section{$\underline{\text { Lab Assessment }}$}

Blood samples were drawn the same day as the appointment. Local clinical labs in each county performed the blood draw according to their standard operating procedures. An experimental draw of six milliliters of blood was obtained by an experienced phlebotomist. Blood samples were sent to Laboratory Corporation of America for lab analysis. Each blood sample had a complete blood count (CBC) analysis. Complete blood count test includes analysis of hemoglobin, hematocrit, mean corpuscular volume (MCV), and red cell distribution width (RDW). Blood samples were 
also analyzed for serum iron, total iron-binding capacity, percent transferrin saturation and serum ferritin. Some blood samples did not have enough blood drawn for analysis. These samples were omitted from the study.

Iron status was based on the lab values of serum ferritin and transferrin saturation. Children were identified in this study as iron sufficient or iron deficient based on serum ferritin and transferrin saturation lab values. Independent Variables- Dietary Factors

Five dietary factors were examined as independent variables for their influence on iron status. If the factor met the criteria one of the two days, the factor was coded as met. Factors included the consumption of an age-appropriate serving of iron-fortified adult or infant cereal, consumption of an age-appropriate serving of meat, fish, or poultry, consumption of an age-appropriate serving of fruit, vegetable, or juice with a meal and intake of a multivitamin supplement. Quantity of cow's milk intake in ounces was obtained on the Diet History Form.

Iron, vitamin $\mathrm{C}$, and calcium intakes were examined for their effects on iron status. Vitamin $\mathrm{C}$ and iron intake are known to enhance the absorption of dietary iron, thus having a positive impact on iron status. Calcium is known to inhibit dietary iron absorption thus having a negative impact on iron status.

Age-appropriate serving sizes were identified for meat, fish, poultry, fruit, vegetable, juice and cereal using the serving size criteria from the USDA Food and Nutrition Service, Child and Adult Care Food Program (CACFP) infant and toddler meal guidelines (United States Department of Agriculture, 2000) (Appendix E). 
Age-appropriate serving sizes for iron-fortified cereal was 1 tablespoon of an iron-fortified infant cereal for infants $6-12$ months and $1 / 4$ cup of an adult iron-fortified cereal for children 13-24 months. Cereals listed in the WIC food list were accepted as iron-fortified adult and infant cereals. Cereals included were Cheerios, Multi-Grain Cheerios, Kix, and Crispex, infant rice cereal, mixed grain infant cereal. Cereals not accepted as iron-fortified cereals were instant oatmeal, Fruit Loops, Lucky Charms, and Apple Jacks.

Age-appropriate serving sizes for meat fish and poultry was 1 tablespoon for infants 6-12 months and $1 \mathrm{oz}$ for children 13-24 months. Meat, fish, or poultry accepted included baked chicken, ground hamburger, ham, hamburger, hot dogs, and bologna. Meat not accepted included pepperoni on pizza, canned chicken noodle soup, and meat combination baby food dinners. In commercially prepared baby food combination dinners the amounts of the various food components are difficult to determine (United States Department of Agriculture, Food and Nutrition Service, 2001). Information on the exact percentages of ingredients is proprietary and thus not available to the public. Given the small percentage of meat required to be in these foods, these dinners were not accepted as a meat source. These dinners generally have less nutritional value by weight than single-ingredient meats and vegetables or fruit mixed together.

Age-appropriate serving sizes for fruits and vegetables were 1 tablespoon for infants 6-12 months and $1 / 4$ cup for 13-24 months of age. Fruits and vegetables accepted included apple slices, applesauce, banana, peaches, peas, carrots, green beans, corn, tomato, cumber, and salad. Only plain fruit or vegetable prepared baby foods were accepted as a fruit or vegetable source. Baby food desserts, and puddings were not 
accepted as a fruit or vegetable sources. Plain commercial baby food vegetables and fruits generally contain more nutrients ounce for ounce and do not usually contain sweeteners or salt (United States Department of Agriculture, Food and Nutrition Service, 2001). Fruited jelly was not accepted as a fruit source.

Age-appropriate serving sizes for juices was 2 ounces for infants 6-12 months and $1 / 4$ cup for 13-24 months of age. Only 100\% juices were accepted as a juice source as juices that are not $100 \%$ juice contain less vitamins and often added sugar (United States Department of Agriculture, Food and Nutrition Service, 2001). Juice accepted as a juice source included orange juice, grape juice, apple juice, and juicy juice. Drinks not accepted as a juice source included Kool-Aid, soda, tea, fruit drinks and punches that were did not contain $100 \%$ fruit juice.

Cow's milk consumption reported as ounces per day, and multivitamin use, were reported by the caregiver.

Dependent Variables- Iron Status

In this study, iron-deficient children were identified by an abnormal lab value of serum ferritin and transferrin saturation. An abnormal serum ferritin value was defined as $\leq 15 \mathrm{ug} / \mathrm{L}$. An abnormal iron transferrin saturation was defined as $\leq 15 \%$. These cut points for iron deficiency are in accordance with CDC's cut off points for iron deficiency diagnosis for children $>6$ months of age (USDHHS, 1998). When either serum ferritin or transferrin saturation were within normal limits, the child was identified as iron sufficient.

In the NHANES II (1976-1980), the definition of iron deficiency was based on three laboratory tests of iron status. These tests included free erythrocyte protoporphyrin, 
transferrin saturation, and serum ferritin. To be considered iron deficient, an individual had to have an abnormal value for two or more indicators. The basis for the use of multiple tests was based on the finding that populations with only one abnormal test of these three, did not have much more iron deficiency than those with all normal test results (Looker et al., 1997).

Iron status can be assessed through several laboratory tests. Because each test assesses a different aspect of iron metabolism, results of one test may not always agree with the results of other tests. No single test is accepted for diagnosing iron deficiency. CDC criteria for the diagnosis of iron deficiency is the abnormal reading of 2 or more iron status lab values (USDHHS, 1998).

\section{$\underline{\text { Statistical Analysis }}$}

Statistical analyses for this study were performed using SAS statistical analysis computer software version 8.0. Stepwise logistic regression was used to evaluate the association between iron deficiency and the independent variables. Multiple regression was used to test relationships between serum ferritin and transferrin saturation and dietary factors. Pearsons correlations were done to show the relationships between iron status indicators and dietary factors. Independent variables used were daily cereal intake of 1 serving per day (yes/no), daily meat/fish/poultry intake of 1 serving per day (yes/no), daily cow's milk intake $>24$ ounces per day (yes/no), daily fruit/vegetable/juice intake of 1 serving per day with a meal (yes/no), daily multivitamin intake (yes/no), average dietary iron intake (mg/day), average dietary vitamin $\mathrm{C}$ intake (mg/day), and average dietary calcium intake (mg/day). Dependent variables included serum ferritin and 
transferrin concentration. All analysis were conducted at $\alpha=.05$. If $\mathrm{p}<\alpha$ than the data analysis were reported as statistically significant. 


\section{CHAPTER 4}

\section{RESULTS}

\section{$\underline{\text { Sample Characteristics }}$}

Table 3: Characteristics of sample

\begin{tabular}{|c|c|c|c|c|}
\hline & $\begin{array}{l}\text { 6-12 Months } \\
(\mathrm{n}=18) \\
\text { Boys }=9 \\
\text { Girls }=9\end{array}$ & $\begin{array}{l}\text { 13-24 months } \\
(\mathrm{n}=32) \\
\text { Boys }=17 \\
\text { Girls }=15\end{array}$ & $\begin{array}{l}\begin{array}{l}\text { Total } \\
(\mathrm{n}=50)\end{array} \\
\text { Boys }=26 \\
\text { Girls }=24\end{array}$ & $\begin{array}{l}X^{2}=0.0451 \\
p=0.83189\end{array}$ \\
\hline $\begin{array}{l}\text { Breastfed Status } \\
\text { (2 missing points) } \\
\text { Never breastfed } \\
\text { Breastfed when left } \\
\text { hospital } \\
\text { Currently breastfed }\end{array}$ & $\begin{array}{l}10 \\
6 \\
2\end{array}$ & $\begin{array}{l}16 \\
10 \\
4\end{array}$ & $\begin{array}{l}26 \\
16 \\
6\end{array}$ & \\
\hline $\begin{array}{l}\text { Mean Weight } \\
\text { (pounds) }\end{array}$ & $20.2 \pm 3.00$ & $26.1 \pm 4.00$ & $24.0 \pm 4.64$ & \\
\hline $\begin{array}{l}\text { Mean Height } \\
\text { (inches) }\end{array}$ & $27.9 \pm 1.48$ & $32.6 \pm 1.64$ & $30.95 \pm 2.74$ & \\
\hline
\end{tabular}

Seventy-five participants were enrolled in a larger study. Three of the 75 children were not between the ages of 6-24 months and 22 children did not have a serum ferritin lab value and therefore were not included in this analysis. Some serum ferritin labs were not available due to insufficient blood drawn to analyze and caregivers not taking children for a blood draw. The data from 50 children 6-24 months of age were included in the study. Table 3 shows characteristics of sample children. Twenty-two of the 50 children were breastfed at some point during infancy. Though breastfeeding contributes to iron status, this aspect was not examined in this study. 
Table 4. Number of children by age group and dietary factors

\begin{tabular}{|c|c|c|c|c|}
\hline & $\begin{array}{l}\text { 6-12 Months } \\
(\mathrm{n}=18)\end{array}$ & $\begin{array}{l}\text { 13-24 Months } \\
(\mathrm{n}=32)\end{array}$ & $\begin{array}{l}\text { Total } \\
(\mathrm{n}=50)\end{array}$ & $\begin{array}{l}\text { Difference } \\
\text { Between } \\
\text { Ages }\end{array}$ \\
\hline $\begin{array}{l}\text { Iron-Fortified Cereal } \\
\text { (\# children consuming } 1 \text { serving /day) } \\
\text { (\# children NOT consuming } 1 \text { serving /day) }\end{array}$ & $\begin{array}{l}14 \\
4\end{array}$ & $\begin{array}{l}17 \\
14\end{array}$ & $\begin{array}{l}31 \\
\frac{18}{49}\end{array}$ & $\begin{array}{l}\mathrm{X}^{2}=2.4811 \\
\mathrm{p}=0.1152\end{array}$ \\
\hline $\begin{array}{l}\text { Meat/Fish/Poultry } \\
\text { (\# children consuming } 1 \text { serving /day) } \\
\text { (\# children NOT consuming } 1 \text { serving /day) }\end{array}$ & $\begin{array}{l}2 \\
16\end{array}$ & $\begin{array}{l}28 \\
3\end{array}$ & $\begin{array}{l}30 \\
\frac{19}{49}\end{array}$ & $\begin{array}{l}X^{2}=19.9692 \\
p=<.0001\end{array}$ \\
\hline $\begin{array}{l}\text { Fruit/Vegetable/Juice } \\
\text { (\# children consuming } 1 \text { serving w/meal) } \\
\text { (\# children NOT consuming } 1 \text { serving w/ } \\
\text { meal) }\end{array}$ & $\begin{array}{l}14 \\
0\end{array}$ & $\begin{array}{l}28 \\
2\end{array}$ & $\begin{array}{l}42 \\
\frac{2}{44} *\end{array}$ & $\begin{array}{l}X^{2}=0.0031 \\
p=0.9557\end{array}$ \\
\hline $\begin{array}{l}\text { Milk } \\
\text { (\# of children consuming } \leq 24 \text { oz per day) } \\
\text { (\# of children consuming }>24 \text { oz per day) }\end{array}$ & $\begin{array}{l}16 \\
2 * *\end{array}$ & $\begin{array}{l}24 \\
6\end{array}$ & $\frac{40}{48^{*}}$ & $\begin{array}{l}X^{2}=0.6233 \\
p=0.4298\end{array}$ \\
\hline $\begin{array}{l}\text { Multivitamin } \\
\text { (\# of children consuming daily) } \\
\text { (\# of children NOT consuming daily) }\end{array}$ & $\begin{array}{l}3 \\
15\end{array}$ & $\begin{array}{l}7 \\
24\end{array}$ & $\begin{array}{l}10 \\
\frac{39}{49}\end{array}$ & $\begin{array}{l}\mathrm{X}^{2}=0.2434 \\
\mathrm{p}=0.6218\end{array}$ \\
\hline
\end{tabular}

**Milk consumption for children $<13$ months- two children, both twelve months old).

*Points with missing data. The entire observation was omitted from a particular analysis when variables with missing data were used.

1. There was not a significant difference in consumption of 1 age-appropriate serving size of iron-fortified adult or infant cereal per day between the 6-12 month and 13-24 month olds, therefore, we accept the hypothesis. The majority of children 6-12 months old were consuming an iron-fortified cereal. Over half of children 13-24 months old were consuming an iron-fortified cereal.

2. There was a significant difference in consumption age-appropriate serving size of meat, fish or poultry per day between the 6-12 month and 13-24 month olds, therefore, we reject the hypothesis. Only two children 6-12 months old were consuming meat, fish or poultry daily. The majority of children 13-24 months old were consuming meat, fish or poultry daily. 
3. There was not a significant difference in consumption of 1 age-appropriate serving size a fruit, vegetable or juice with one meal during the day between the 6-12 month and 13-24 month olds, therefore, we accept the hypothesis. All children 6-12 months old were consuming a fruit, vegetable or juice serving with a meal. The majority of children 13-24 months old were also consuming a fruit, vegetable or juice serving with a meal.

4. There was not a significant difference in consumption of cow's milk greater than 24 ounces per day between the 6-12 month and 13-24 month olds, therefore, we accept the hypothesis. The two children 6-12 months old that consumed cow's milk, were 12 months old. The majority of children 13-24 months old consumed the recommended less than 24 ounces of cow's milk per day.

5. There was not a significant difference in intake of a daily multivitamin between the 6-12 month and 13-24 month olds, therefore, we accept the hypothesis. The majority of children were not consuming a daily multivitamin.

Table 5. Nutrient intake by age

\begin{tabular}{|c|c|c|c|c|}
\hline & $\begin{array}{l}\text { 6-12 Months } \\
(\mathrm{n}=18)\end{array}$ & $\begin{array}{c}13-24 \text { months } \\
(n=32)\end{array}$ & $\begin{array}{c}\text { Total } \\
(n=50)\end{array}$ & $\begin{array}{c}\text { Difference } \\
\text { Between } \\
\text { Ages }\end{array}$ \\
\hline $\begin{array}{l}\text { Iron Intake } \\
(\mathrm{mg} / \text { day })\end{array}$ & $\begin{array}{l}15.3 \pm 5.83 \\
(136 \% \mathrm{DRI}) \\
\text { DRI } 11 \mathrm{mg} / \text { day }\end{array}$ & $\begin{array}{l}4.9 \pm 2.92 \\
(70 \% \text { DRI) } \\
\text { DRI } 7 \mathrm{mg} / \mathrm{day} \\
\end{array}$ & $12.0 \pm 5.80$ & $\begin{array}{l}X^{2}=7.9871 \\
p=0.0047\end{array}$ \\
\hline $\begin{array}{l}\text { Vitamin C } \\
\text { (mg/day) }\end{array}$ & $\begin{array}{l}134.5 \pm 58.43 \\
(269 \% \text { DRI }) \\
\text { DRI } 50 \mathrm{mg} / \text { day }\end{array}$ & $\begin{array}{l}103.0 \pm 58.41 \\
(687 \% \text { DRI }) \\
\text { DRI } 15 \mathrm{mg} / \text { day }\end{array}$ & $114.5 \pm 59.81$ & $\begin{array}{l}X^{2}=2.9453 \\
p=0.0861\end{array}$ \\
\hline $\begin{array}{l}\text { Calcium } \\
\text { (mg/day) }\end{array}$ & $\begin{array}{l}602.0 \pm 216.63 \\
(223 \% \mathrm{DRI}) \\
\text { DRI } 270 \mathrm{mg} / \text { day }\end{array}$ & $\begin{array}{l}939.7 \pm 311.2 \\
(188 \% \mathrm{DRI}) \\
\text { DRI } 500 \mathrm{mg} / \text { day }\end{array}$ & $813.0 \pm 322.5$ & $\begin{array}{l}X^{2}=9.4294 \\
p=0.0021\end{array}$ \\
\hline
\end{tabular}


6. There was a significant difference in dietary iron intake between the 6-12 month and 13-24 month olds, therefore, we reject the hypothesis. Children 13-24 months did not meet the DRI for iron.

7. There was not a significant difference in dietary vitamin $\mathrm{C}$ intake between the 612 month and 13-24 month olds, therefore, we accept the hypothesis. Both groups exceeded the DRI for vitamin C.

8. There was a significant difference in dietary calcium intake between the $6-12$ month and 13-24 month olds, therefore, we reject the hypothesis. Both groups were exceeding DRI's for calcium.

Table 6. Iron status by age group.

\begin{tabular}{|l|l|l|l|l|}
\hline & $6-12$ Months $(\mathrm{n}=18)$ & $13-24$ Months $(\mathrm{n}=32)$ & Total $(\mathrm{n}=50)$ & $\begin{array}{c}\text { Difference } \\
\text { Between } \\
\text { Ages }\end{array}$ \\
\hline $\begin{array}{l}\text { Iron Status } \\
\text { Sufficient }\end{array}$ & $\begin{array}{l}17^{*}(94 \%)^{* *} \\
\text { Deficient }\end{array}$ & $\begin{array}{l}20(63 \%) \\
12(37 \%)\end{array}$ & $\begin{array}{l}37(74 \%)^{* * *} \\
13(26 \%)\end{array}$ & $\begin{array}{l}\mathrm{X}^{2}=4.5241 \\
\mathrm{p}=0.0334\end{array}$ \\
\hline $\begin{array}{l}\text { Serum Ferritin } \\
\text { Mean (ug/dL) }\end{array}$ & $40.5 \pm 23.99$ & $18.7 \pm 14.61$ & $26.5 \pm 21.16$ & \\
$>15 \mathrm{ug} / \mathrm{dL}$ & $15(83 \%)$ & $11(34 \%)$ & $26(52 \%)$ & $\mathrm{X}^{2}=9.4508$ \\
$\leq 15 \mathrm{ug} / \mathrm{dL}$ & $3(17 \%)$ & $21(66 \%)$ & $24(48 \%)$ & $\mathrm{p}=0.0021$ \\
\hline Transferrin Saturation & & $15.5 \pm 8.22$ & $16.9 \pm 8.47$ & \\
Mean (ug/dL) & $19.1 \pm 8.66$ & $18(56 \%)$ & $24(48 \%)$ & $\mathrm{X}^{2}=2.3657$ \\
$>15 \%$ & $6(33 \%)$ & $14(44 \%)$ & $26(52 \%)$ & $\mathrm{p}=0.1240$ \\
\hline $15 \%$ & $12(67 \%)$ & &
\end{tabular}

*Number of children

$* *$ Percent of children in the age group

$* * *$ Percent of total children

Based on the study criteria for iron deficiency, six percent of the 6-12 month olds was iron deficient and thirty-seven percent of the children 13-24 months old were iron deficient. There was a significant difference in the number of children 6-12 months and 13-24 months old that were iron deficient. A majority of the children found to be iron deficient in this study were children 13-24 months old. Overall, there was a large 
percentage of 13-24 month that were iron deficient. These findings are consistent with a study by Soh et al. (2002) which showed a higher prevalence of iron deficiency among 13-24 months olds than among 6-12 months olds. There was a significant difference in serum ferritin between 6-12 month and 13-24 month olds. There was not a significant difference in transferring saturation between 6-12 month and 13-24 month olds.

Dietary factors and iron status

Daily iron-fortified cereal intake $\left(\mathrm{X}^{2=} 4.1092, \mathrm{p}=0.0427\right)$ and calcium intake $\left(\mathrm{X}^{2}=\right.$ 5.4844, $\mathrm{p}=0.0192)$ were both independent predictors of iron status for all children $\left(\mathrm{X}^{2}=\right.$ 11.9749, $\mathrm{p}=0.0025)$. Twenty-five percent of the variance in iron status was due to cereal and calcium intakes $\left(r^{2}=0.2481\right)$. When the age groups were looked at separately, daily iron-fortified cereal consumption predicted iron status for children 13-24 months old $\left(\mathrm{X}^{2}=4.3155, \mathrm{p}=0.0378\right)$. Fifteen percent of the variance in iron status in $13-24$ months olds was due to daily iron-fortified cereal intake $\left(\mathrm{r}^{2}=0.1562\right)$. No other dietary factors were found to be significant.

9. There was a significant difference in iron status of children 6-24 months of age who consumed 1 age-appropriate serving size of an iron-fortified adult or infant cereal per day compared to those who didn't, therefore we reject the hypothesis.

10. There was not a significant difference in iron status of children 6-24 months of age who consume 1 age-appropriate serving size of meat, fish or poultry per day compared to those who didn't, therefore, we accept the hypothesis.

11. There was not a significant difference in iron status of children 6-24 months of age who consumed 1 age-appropriate serving size a fruit, vegetable or juice with 
one meal during the day compared to those who didn't, therefore, we accept the hypothesis.

12. There was not a significant difference in iron status of children 6-24 months old who consumed greater than 24 ounces/day of cow's milk per day compared to those who didn't, therefore, we accept the hypothesis.

13. There was not a significant difference in iron status of children 6-24 months old who consumes a daily multivitamin compared to those who didn't, therefore, we accept the hypothesis.

14. There was not a difference in iron status of children 6-24 months old with dietary iron intake, therefore, we accept the hypothesis.

15. There was not a significant difference in iron status of children 6-24 months old with dietary vitamin $\mathrm{C}$ intake, therefore, we accept the hypothesis.

16. There was a significant difference in iron status of children 6-24 months old with dietary calcium intake, therefore we reject the hypothesis.

\section{Dietary factors and serum ferritin}

Serum ferritin reflects total body iron stores. It is sometimes used as an early indicator of iron deficiency. Many studies have examined dietary factors influence on serum ferritin alone with this in mind (Cowin, et al., 2001; Gibson, 1999; Soh et al., 2002). 
Table 7A Average serum ferritin and dietary factors for all children

\begin{tabular}{|c|c|c|c|c|c|c|}
\hline Dietary Factor & $(\mathrm{n}=) \underline{\mathrm{Nc}}$ & $\frac{\text { consumed }}{\mathrm{ug} / \mathrm{dL} \pm \mathrm{SD}}$ & $(n=)$ & $\frac{\text { onsumed }}{\mathrm{ug} / \mathrm{dL} \pm \mathrm{SD}}$ & t-test & $\mathrm{p}$-value \\
\hline Cereal & $(n=18)$ & $23.9 \pm 22.78$ & $(n=31)$ & $28.71 \pm 20.38$ & -0.76 & 0.4483 \\
\hline Meat/Fish/Poultry & $(\mathrm{n}=19)$ & $37.8 \pm 24.41$ & $(\mathrm{n}=30)$ & $20.0 \pm 15.68$ & 3.12 & 0.0031 \\
\hline $\begin{array}{l}\text { Fruit/ } \\
\text { Vegetable/Juice }\end{array}$ & $(n=2)$ & $14.5 \pm 10.61$ & $(n=42)$ & $25.2 \pm 19.49$ & -0.77 & 0.4469 \\
\hline $\begin{array}{l}\text { Milk consumption } \\
>24 \text { ounces }\end{array}$ & $(n=40)$ & $29.7 \pm 21.97$ & $(n=8)$ & $14.9 \pm 12.03$ & 1.85 & 0.0713 \\
\hline Multivitamin & $(n=39)$ & $27.6 \pm 22.79$ & $(n=10)$ & $24.2 \pm 13.77$ & 0.45 & 0.6516 \\
\hline $\begin{array}{l}\text { Iron-Fortified } \\
\text { Formula }\end{array}$ & $(n=31)$ & $19.0 \pm 14.68$ & $(n=17)$ & 14.68 & -3.96 & 0.0003 \\
\hline
\end{tabular}

Table 7B. Average serum ferritin and dietary factors for children 6-12 months*

\begin{tabular}{|c|c|c|c|c|c|c|}
\hline \multirow[t]{2}{*}{ Dietary Factor } & \multicolumn{2}{|c|}{ Not consumed } & \multicolumn{2}{|c|}{ Consumed } & \multirow[t]{2}{*}{ t-test } & \multirow[t]{2}{*}{ p-value } \\
\hline & $(\mathrm{n}=)$ & $\mathrm{ug} / \mathrm{dL} \pm \mathrm{SD}$ & $(\mathrm{n}=)$ & $\mathrm{ug} / \mathrm{dL} \pm \mathrm{SD}$ & & \\
\hline Cereal & $(n=4)$ & $53.5 \pm 21.27$ & $(n=14)$ & $36.9 \pm 24.13$ & 1.24 & 2318 \\
\hline Meat/Fish/Poultry & $(n=16)$ & $41.5 \pm 23.94$ & $(n=2)$ & $33.0 \pm 32.53$ & 0.46 & 0.6508 \\
\hline $\begin{array}{l}\text { Milk consumption } \\
>24 \text { ounces }\end{array}$ & $(n=16)$ & $44.2 \pm 22.92$ & $(n=2)$ & $11.5 \pm 2.12$ & 1.96 & 0.0673 \\
\hline Multivitamin & $(n=15)$ & $43 \pm 24.61$ & $(n=3)$ & $28.3 \pm 19.60$ & 0.96 & 0.3491 \\
\hline
\end{tabular}

*No children found to consume fruit, vegetable, or juice with a meal

Table 7C. Average serum ferritin and dietary factors for children 13-24 months

\begin{tabular}{|c|c|c|c|c|c|c|}
\hline Dietary Factor & & consumed & & nsumed & t-test & p-value \\
\hline & $(\mathrm{n}=)$ & $\mathrm{ug} / \mathrm{dL} \pm \mathrm{SD}$ & $(n=)$ & $\overline{\mathrm{ug} / \mathrm{dL}} \pm \mathrm{SD}$ & & \\
\hline Cereal & $(n=14)$ & $15.4 \pm 15.07$ & $(n=17)$ & $22 \pm 14.14$ & -1.25 & 0.2211 \\
\hline Meat/Fish/Poultry & $(n=3)$ & $18.3 \pm 19.55$ & $(n=28)$ & $19.1 \pm 14.55$ & -0.09 & 0.9327 \\
\hline $\begin{array}{l}\text { Fruit/ } \\
\text { Vegetable/Juice }\end{array}$ & $(n=2)$ & $14.5 \pm 10.61$ & $(n=28)$ & $19.9 \pm 15.05$ & -0.49 & 0.6273 \\
\hline $\begin{array}{l}\text { Milk consumption } \\
>24 \text { ounces }\end{array}$ & $(n=25)$ & $19.8 \pm 15.05$ & $(n=6)$ & $16 \pm 13.99$ & 0.56 & 0.5823 \\
\hline Multivitamin & $(n=24)$ & $18.0 \pm 15.48$ & $(n=7)$ & $22.4 \pm 12.01$ & -0.69 & 0.4965 \\
\hline
\end{tabular}

Table 7 shows the relationship between when serum ferritin and dietary factors.

For children not consuming meat/fish/poultry the mean serum ferritin value was

$37.8 \mathrm{ug} / \mathrm{dL} \pm 24.41$. For children consuming meat, fish, or poultry daily the mean ferritin value was $20.0 \pm 15.68(\mathrm{p}=0.0031)$. Formula intake was also examined as a predictor of serum ferrtin in 6-12 month old children since this age group had a higher mean ferritin 
than the children 13-24 months. Sample size of infants consuming formula was too small to draw accurate conclusions for this analysis although mean serum ferritin of children consuming an iron-fortified formula was $(41.4 \mathrm{ug} / \mathrm{dL} \pm 24.45)$ and the mean serum ferritn for children not consuming an iron-fortified formula was (19.0 ug/dL \pm 14.68$)$. When the data for ages 6-12 months and ages 13-24 months were separated and tested, there was no significant dietary factors that affected serum ferritin.

17. There was not a significant difference in serum ferritin of children 6-24 months of age who consumed 1 age-appropriate serving size of an iron-fortified adult or infant cereal per day compared to those who didn't, therefore, we accept the hypothesis.

18. There was a significant difference in serum ferritin of children 6-24 months of age who consumed 1 age-appropriate serving size of meat, fish or poultry per day compared to those who didn't, therefore we reject the hypothesis.

19. There was not a significant difference in serum ferritin of children 6-24 months of age who consume 1 age-appropriate serving size a fruit, vegetable or juice with one meal during the day compared to those who didn't, therefore we accept the hypothesis.

20. There was not a significant difference in serum ferritin of children 6-24 months old who consume greater than 24 ounces/day of cow's milk per day compared to those who didn't consume greater than 24 ounces per day of cow's milk, therefore, we accept the hypothesis. Results for all children and children 6-12 months old approached significance, but were not significant. 
21. There was not a significant difference in serum ferritin of children 6-24 months old who consumed a daily multivitamin compared to those who didn't, therefore we accept the hypothesis.

Table 8A. Simple Linear Regression 2 day average nutrient intake and serum ferritin for all children

\begin{tabular}{|l|l|l|l|}
\hline Nutrient & $\mathrm{r}^{2}$ & t-value & $\mathrm{p}$-value \\
\hline Iron & 0.0430 & 1.45 & 0.1526 \\
\hline Vitamin C & 0.0339 & 1.29 & 0.2051 \\
\hline Calcium & 0.2434 & -3.85 & 0.0004 \\
\hline
\end{tabular}

Table 8B. Simple Linear Regression 2 day average nutrient intake and serum ferritin for 6-12 month olds

\begin{tabular}{|l|l|l|l|}
\hline Nutrient & $\mathrm{r}^{2}$ & $\mathrm{t}$-value & $\mathrm{p}$-value \\
\hline Iron & 0.0007 & -0.10 & 0.9177 \\
\hline Vitamin C & 0.0124 & 0.45 & 0.6603 \\
\hline Calcium & 0.0401 & 3.12 & 0.0067 \\
\hline
\end{tabular}

Table 8C. Simple Linear Regression 2 day average nutrient intake and serum ferritin for 13-24 month olds

\begin{tabular}{|l|l|l|l|}
\hline Nutrient & $\mathrm{r}^{2}$ & $\mathrm{t}$-value & $\mathrm{p}$-value \\
\hline Iron & 0.0000 & 0.01 & 0.9941 \\
\hline Vitamin C & 0.0010 & 0.17 & 0.8639 \\
\hline Calcium & 0.1966 & -2.62 & 0.0141 \\
\hline
\end{tabular}

22. There was not a significant difference in serum ferritin of children 6-24 months old with dietary iron intake, therefore, we accept the hypothesis.

23. There was not a significant difference in serum ferritin of children 6-24 months old with dietary vitamin C intake, therefore, we accept the hypothesis.

24. There was a significant difference in serum ferritin of children 6-24 months old with dietary calcium intake, therefore, we reject the hypothesis. Calcium was the only nutrient related to serum ferritin. It was related for both groups together and separately. 
In table $8 \mathrm{~A}$ and $8 \mathrm{~B}$, the $\mathrm{t}$-value for calcium was negative. This indicates an inverse relationship of calcium and serum ferritin. As expected, calcium intake increases (a known iron absorption inhibitor), iron stores decrease. Table $8 \mathrm{~B}$ shows a positive tvalue for calcium. This is contrary to our expectation. In this case, it is possible that dietary calcium is supplied from iron-fortified formula or breast milk intake. In the 6-12 months olds, calcium may be a marker for iron-fortified formula or breast milk intake rather than calcium intake from a dairy product (a poor source of iron). In the 13-24 month olds, calcium intake is a marker for dairy product intake which does not contain iron.

Table 9. Pearson correlations of average nutrient intake and iron status indicators

\begin{tabular}{|l|c|c|c|}
\hline & \multicolumn{1}{|c|}{ Iron } & Vitamin C & Calcium \\
\hline Serum Ferritin & $0.2075(\mathrm{p}=0.1526)$ & $0.1842(\mathrm{p}=0.2051)$ & $-0.4934(\mathrm{p}=0.0004)$ \\
\hline Transferrin Saturation & $0.0523(\mathrm{p}=0.7239)$ & $-0.0485(\mathrm{p}=0.7435)$ & $-0.0820(\mathrm{p}=0.5840)$ \\
\hline
\end{tabular}

Serum ferritin and calcium intake were negatively and moderately assocatiated $(\mathrm{r}=-0.4934, \mathrm{p}=0.004)$. Serum ferritin and iron intake were positively and weak to moderately associated. This association was not significant $(r=0.2075, p=0.1526)$.

When multiple regression was analyzed for transferrin saturation and dietary factors and nutrient intake, none of the variables predicted transferrin saturation. It is known that transferrin saturation is not a sensitive predictor of iron deficiency and therefore this is to be expected.

When multiple regression was analyzed for serum ferritin with dietary factors and nutrient intake, it was found that meat, fish, and poultry intake was a significant predictor of serum ferritin $(\mathrm{p}=0.0177)$. Calcium intake was also found be a predictor of serum ferritin $\left(\mathrm{r}^{2}=0.24344\right.$, $\mathrm{t}$-value $\left.=-3.85, \mathrm{p}=0.0004\right)$. 


\section{CHAPTER 5}

\section{DISCUSSION}

This study aimed to determine whether West Virginia WIC participants ages 6-24 months were iron deficient if they followed the CDC's recommendations to prevent iron deficiency. Based on the criteria defined for iron deficiency of this study using serum ferritin levels and transferrin saturation, $26 \%$ of the children were iron deficient. Six percent of children 6-12 month olds were iron deficient and 37\% of the children 13-24 months were iron deficient. A majority of the iron deficient children were from the 13-24 month old group (24\% of all children were 13-24 months old). This is consistent with the findings from a study from Soh et al. (2002) that found a more prevalent number of 13-24 months old children iron deficient as compared to 6-12 month olds. The results of this study demonstrated that iron deficiency among this population still exists despite efforts to prevent iron deficiency.

Recent studies have examined the relationship of dietary patterns in infants and young children on iron status (Thane et al.,2000; Gibson, 1999; Soh et al., 2002, OtiBoateng, 1998; Spodaryk, 1999; Cowin et al., 2001). CDC has emphasized that primary prevention of iron deficiency should achieved through the diet. CDC and other agencies including Maternal Child Health Bureau and American Academy of Family Physicians have issued dietary recommendations as strategies to achieve primary prevention of iron deficiency. Dietary strategies include eating one serving of an iron-fortified adult or infant cereal per day; eating meat, fish or poultry daily; eating a fruit, vegetable or juice with meals; drinking no more than 24 ounces cow's milk per day; and daily intake of a multivitamin. In this study, sixty two percent (31 children) consumed one serving of 
iron-fortified adult or infant cereal per day, $60 \%$ (30 children) consumed one serving of meat/fish/poultry per day, $84 \%$ (42 children), ate one serving fruit/vegetable/juice with one meal per day, $80 \%$ (40 children) consumed 24 ounces or less of cow's milk per day, $20 \%$ ( 10 children) consumed a multivitamin daily. The majority of the children in this study were following iron deficiency dietary recommendations, but improvements can be made with all of the above recommendations in this population

All children 6-12 months old met the DRI for iron intake while $72 \%$ of $13-24$ month old children did not meet the DRI for iron intake. The average iron intake of children 13-24 months was 4.9mg \pm 2.92 (DRI $7 \mathrm{mg} /$ day). Many studies have shown that up to the age of 12 months, when the infant transitions from breast milk or ironfortified infant formula to cow's milk and table foods, iron status is usually adequate (Soh et al., 2002). At 13 months, the children's dietary patterns change and often do not include iron rich foods.

All children exceeded dietary vitamin $\mathrm{C}$ recommendations (Institute of Medicine, 2000). The children 6-12 months exceeded their vitamin $C$ recommendation by 1.6 times and the 13-24 months olds exceeded the recommendation by 5.8 times. The determination of the DRI for vitamin $\mathrm{C}$ for children 6-12 months of age is based on data of infants fed breast milk which is considered the optimal nutrient source for infants. The adequate intake (AI) was set at the mean value for observed intake of this age group. On average they consumed $22 \mathrm{mg}$ of vitamin C per day from solid foods and $27 \mathrm{mg}$ /day from milk. The AI was rounded to $50 \mathrm{mg} /$ day. The data from the 1996 CSFII (Continuing Survey of Food Intakes by Individual), showed that for infants 7-12 months daily vitamin $\mathrm{C}$ intake ranged from 21-293 mg/day with a median intake of $106 \mathrm{mg} /$ day of vitamin C 
(Institute of Medicine, 2000). The present study showed similar vitamin C intakes of $134.5 \mathrm{mg} /$ day. The RDA for children 1-3 years is based on adult studies. It takes into account a body weight difference between children and adults by assuming a coefficient of variation of 10\%. It is therefore set at $15 \mathrm{mg} /$ day (Institute of Medicine, 2000).

Children 13-24 months old in the present study consumed 5 times the amount of vitamin C recommended by the Food and Nutrition Board, Institute of Medicine and National Academy of Science. Oranges and other citrus foods are often thought of as sources of vitamin C. Potatoes are also a good source of vitamin C. Many of the diets of the children of this study contained potatoes including french fries, potato chips, mashed potatoes, boiled potatoes, or baked potatoes. It is also important to note that many fruit drinks, including Hi-C and Kool-Aid, are fortified with vitamin C contributing to the daily vitamin $\mathrm{C}$ intake.

All children met and exceeded dietary calcium nutrient recommendations (Institute of Medicine, 1997). The adequate intake (AI) for calcium in infants 7-12 months reflects the derived mean intake of breast fed infants, $264 \mathrm{mg}$ per day (Institute of Medicine, 1997). The infants in the present study consumed calcium 1.2 times the AI. Diet records revealed that infants were consuming between 24-32 ounces of an ironfortified formula per day. A child consuming 24 ounces of a standard iron-fortified formula would receive $390 \mathrm{mg}$ of calcium per day. In addition, many in this age group also ate pudding ( $150 \mathrm{mg}$ calcium per $1 / 2$ cup), and cheese slices ( $288 \mathrm{mg}$ calcium per slice). This would account for the additional calcium they were receiving. For children 1-3 years of age the AI for calcium was based on the net daily accretion of calcium of $100 \mathrm{mg} /$ day. It was estimated there is a $20 \%$ net calcium retention for this age group. 
The AI was set at $500 \mathrm{mg} /$ day to achieve the $100 \mathrm{mg}$ per day retention although further investigations are needed to more precisely estimate calcium needs (Institute of Medicine, 1997). The 1994 CSFII data showed the medium calcium intake of 766 $\mathrm{mg} /$ day. This falls between the $10^{\text {th }}$ percentile and $25^{\text {th }}$ percentile for calcium intake. The present study showed that children 13-24 months consumed over 0.5 times calcium than the AI as recommended. Sources of calcium in 13-24 month old diets included cow's milk, pudding, and cheese slices. The median calcium intake in this study exceeds the median calcium intake for children in the CSFII.

The results of this study showed that the intake of one serving of an iron-fortified adult or infant cereal intake together with calcium intake were predictors of iron status for all children. Cereal is generally consumed with milk which contains calcium. Cereals examined in this study for their relationship to iron status were iron-fortified cereals. Calcium is known to inhibit iron absorption. Cereal and calcium intake presenting together as indicators of iron status of all children could indicate that calcium from the milk is inhibiting iron absorption from the cereal. Future studies could examine this relationship.

When looked at separately, cereal and calcium intake were predictors of iron status on their own. Calcium is known to inhibit iron absorption and therefore affect iron status. This study showed that calcium intake alone was a predictor for iron status in all children. Iron and vitamin $\mathrm{C}$ intake were not predictors of iron status. A study by Thane et al found few associations between poor iron status and intakes of individual nutrients (including supplements) (Thane et al., 2000). 
Iron-fortified cereals are a good source of dietary iron in children's diets. A study by Soh showed that cereal contributed 31\% of toddlers daily dietary iron intake (Soh et al., 2002). The present study did not quantify the percent of total dietary iron intake obtained from cereal, but showed that cereal intake was related to iron status. This was likely due to the iron content of cereal that provided a good source of iron in children's diets.

When the age groups were looked at separately it was found that among the 13-24 month olds, daily iron-fortified cereal consumption predicted iron status. Iron-fortified cereals are a good source of iron in children's' diets. A study by Soh et al showed that toddlers consuming iron-fortified cereal had a 1.03 greater likelihood of having good iron stores (serum ferritin $\geq 20 \mathrm{ug} / \mathrm{L}$ ) (Soh et al., 2002). The present study showed that $53 \%$ of 13-24 months olds, and 78\% of 6-12 month olds consumed one serving of an ironfortified cereal at least one of the two days obtained and that cereal intake was a predictor of iron status. This is consistent with Sohs' study that showed that cereal increased likelihood of good iron stores in toddlers (Soh et al., 2002).

Statistical analysis failed to show significant predictor relationship of iron status to cow's milk consumption $>24$ ounces per day, fruit vegetable or juice consumption with a meal, meat consumption, daily multivitamin intake, vitamin $\mathrm{C}$ intake and iron intake.

In this study, serum ferritin and transferrin saturation were used as indicators of iron status. Many studies have examined the influence of dietary factors on serum ferritin alone. Ferritin levels reflect total iron stores and are an early indicator of iron deficiency. Ferritin is however, also an acute phase protein and may be raised acutely in 
response to infection or other stress. Care must be taken when drawing conclusions about iron deficiency using serum ferritin alone (Cowin et al., 2001). In this study, forty eight percent of the children had low serum ferritin levels $(\leq 15 \mathrm{ug} / \mathrm{dL})$ compared to $24 \%$ iron deficient based on serum ferritin and transferrin saturation.

Table 7A shows that the intake of one serving of meat, fish or poultry daily was predictive of serum ferritin for all children. Simple linear regression of average nutrient intake and dietary factors showed an association of serum ferritin and calcium for all children and for both age groups when data was separated by age. No other significant associations were found with serum ferritin and dietary factors or nutrient intakes, although milk consumption $>24$ ounces per day approached statistical significance for 612 month old children and for all children.

Meat, fish and poultry are good sources of iron. This study showed that meat, fish or poultry intake was predictive of serum ferritin for all children (Table 7A). It is expected that a positive relationship exists between meat, fish, and poultry intake and iron stores (indicated by serum ferritin). A study by Thane et al did find a positive association between meat intake and serum ferritin in children 1.5- 4.5 years old (Thane et al., 2000). A study by Gibson et al. found that meat intake was beneficial to hemoglobin levels (late indicator of iron deficiency) only when the child also consumed adequate vitamin $\mathrm{C}$ and cereal (Gibson, 1999). Soh et al found no significant relationship with meat intake and serum ferritin (Soh et al., 2002). These studies do not consistently show a relationship of meat intake alone and serum ferritin.

The mean serum ferritin for children not consuming meat, fish or poultry was $37.8 \mathrm{ug} / \mathrm{L} \pm 24.41$ (Table 7A). This is peculiar because the mean serum ferritin for 
children not consuming meat, fish or poultry $(37.8 \mathrm{ug} / \mathrm{L} \pm 24.41)$ is higher than the mean serum ferritin for children consuming meat, fish or poultry $(20.0 \mathrm{ug} / \mathrm{L} \pm 15.68)$. It is expected that the children consuming meat, fish, or poultry would have a higher mean serum ferritin than those children not consuming meat, fish or poultry. This can be explained by looking at Table 7B which shows that children 6-12 months of age had higher mean serum ferritin values in the not consuming column than the children 13-24 months in the not consuming column. Table 7A shows that 19 children did not consume meat, fish or poultry. Sixteen out of the nineteen non consumers of meat, fish, or poultry were 6-12 months of age and had higher mean serum ferritin levels than the 13-24 month olds. The 6-12 month old mean serum ferritin values contributed heavily to the not consumers of meat, fish or poultry in table 7A. The higher 6-12 month olds mean serum ferritin values may result from their other dietary factors including iron-fortified infant formula and cereal or breast milk intake.

Simple linear regression of average nutrient intake and dietary factors showed an association of serum ferritin and calcium for all children and for both age groups when data was separated by age. Other studies have also found a relationship between serum ferritin and calcium intake. Soh et al. found a negative association with of calcium intake and serum ferritin (Soh et al., 2002). Cowin et al, found that for every $100 \mathrm{mg}$ of calcium consumed there was a 4-5\% drop in ferritin levels (Cowin et al., 2001). This is consistent with the known inhibitory impact of calcium on iron absorption. Although the results of the present study concerning the relationship of calcium and serum ferritin did not approach statistically significant, many other studies have found a relationship is worth discussion and further examination. 
CDC recommends that children consume 24 ounces or less of cow's milk per day to prevent iron deficiency (USDHHS, 1998). Two children in this study 6-12 months (both 12 months old) and six children 13-24 months consumed more than 24 ounces of cow's milk per day. It is not typical to see children 6-12 months of age consuming cow's milk although early consumption of cow's milk has been known to result in iron deficiency in early childhood. The two children in the 6-12 month old group drinking cow's milk were both 12 months old. It is common for children at this age to be transitioning to cow's milk. In these two children, all the dietary factors, except milk consumption, were adequate according to the recommendations to prevent iron deficiency. These two still presented with low serum ferritin levels. One of the 12 month old drank 40 ounces cow's milk per day (serum ferritin 10ug/dL) and the other 32 ounces per day (serum ferritin 13ug/dL). Both children had adequate iron intake respectively $(16.95 \mathrm{mg} /$ day, $17.96 \mathrm{mg} /$ day, Iron DRI $11 \mathrm{mg} /$ day $)$, ate one serving of meat per day, ate fruit/vegetable/ juice with a meal, and consumed one serving of iron-fortified cereal per day. The present study results for 6-24 month olds of serum ferritin and cow's milk consumption show that serum ferritin cannot be predicted by consumption of $>24$ ounces of milk per day ( $\mathrm{p}=0.0673)$, but results approached statistical significant. Limiting cow's milk consumption to 24 ounces per day for children should still be encouraged as currently recommended by the CDC.

Among children 13-24 months, six (19\%) consumed greater than 24 ounces of cow's milk per day. In this study, milk consumption for children 13-24 months was not a statistical significance predictor of serum ferritin. For all children in this study, calcium 
intake but not milk consumption greater than 24 ounces per day was predictive of serum ferritin.

Other studies have shown that a high cow's milk consumption is a risk factor for iron deficiency among children. A study in Britain found that milk intake was inversely associated with iron status among young children (Thane et al., 2000). Children who consumed $>16$ ounces of milk and cream per day were less likely to consume foods from other groups including meats and meat products. They found the prevalence of poor iron status was greater in children consuming $>16$ ounces milk per day compared with those consuming $<16$ ounces of milk per day ( $9 \%$ vs. $2 \%$ p $=0.02$ ) (Thane et al., 2000). They also found that low ferritin levels were associated with high intakes of calcium. Another study by Cowin et al., also showed that higher levels of milk in the diet are associated with lower ferritin levels in 18 month old children (Cowin et al., 2001). A study by Soh et al, showed calcium intakes were negatively associated to serum ferritin (Soh et al., 2002). The present study did not show a significant association between ferritin levels and milk intake although results approached statistical significant.

CDC recommends that children include a fruit, vegetable or juice with meals (USDHHS, 1998). This recommendation is likely to encourage the intake of vitamin C with meals to enhance the absorption of dietary iron. All children were exceeding the DRI vitamin C intake for the two day average (6-12 months olds consumed 269\%, 134.5 mg DRI and 13-24 month olds consumed 687\%, 50mg DRI). Excess vitamin C intake is not harmful and may be excreted in urine. Vitamin $\mathrm{C}$ is also known to enhance iron absorption when consumed simultaneously with iron. Eighty eight percent (44 children) of children were consuming fruit, vegetable or juice with a meal. Intake of fruit, 
vegetable or juice was not found to be a significant predictor of iron status and dropped out of the model.

CDC recommends that children consume meat, fish, or poultry one time per day to prevent iron deficiency (USDHHS, 1998). In this study $30(60 \%)$ children consumed meat once per day. Only $2(11 \%)$ children 6-12 months consumed one serving of meat, and $28(88 \%)$ children 13-24 months were consuming a meat serving per day. Average iron intake for children 6-12 months was $15.3 \mathrm{mg} \pm 5.83($ DRI $11 \mathrm{mg} /$ day $)$ and for children 12-24 months $4.9 \mathrm{mg} \pm 2.92(\mathrm{DRI} 7 \mathrm{mg} /$ day $)$. Results showed that although meat consumption per day differed between children with sufficient iron status and insufficient iron status, it did not predict total iron status as shown in logistic regression.

When serum ferritin was tested against dietary factors daily intake of meat/fish/poultry was associated with serum ferritin status. It is interesting to note that the mean serum ferritin values for those who did not consume meat, fish, or poultry $(37.8$ ug/dL+-24.41) were higher than those consuming meat/fish/poultry daily $(20.0 \mathrm{ug} / \mathrm{dL}+-$ 15.68). Only 3 children from the 13-24 month old group and 16 from the 6-24 month old group were not consuming a meat serving per day. The mean ferritin for 6-12 month olds $(40.5 \mathrm{ug} / \mathrm{dL} \pm 23.99)$ is higher than for $13-24$ month olds $(18.7 \mathrm{ug} / \mathrm{dL} \pm 14.61)$. These results are not consistent with the results of the study by Soh et al (Soh et al., 2002). They did not find an association between iron stores and meat/fish/poultry intake. They concluded that the lack of association was related to the low intake of heme iron.

The American Academy of Family Physicians recommend the daily intake of an iron-fortified vitamin, especially in the second year of life, to prevent iron deficiency (Kazal, 2002). In this study 10 children (20\%) consumed a multivitamin daily. Three 
were 6-12 months olds and seven were 13-24 month olds, however, in this study, multivitamin use did not predict iron status.

Bright Futures in Practice publication supported by the Maternal and Child Health Bureau states that the consumption of an iron-fortified cereal can help iron status (Story et al., 2002). In this study, 62\% (31 children) consumed one serving of an iron-fortified adult or infant cereal. This study's results show that cereal intake can predict iron status.

As to be expected, Pearson correlations show that serum ferritin and average calcium intake are moderately negatively correlated. Calcium is known to inhibit iron absorption. There is weak correlation between serum ferritin and iron intake.

This study has some limitations. Obtaining diet recalls by 24-hour dietary recalls has limitations. Participants may not remember accurately foods consumed the previous day. The lower income population may not know how to measure foods and therefore not report serving sizes consumed accurately. Nutrient analysis using software sometimes does not have food items in the food bank that were reported by the participants. Foods selected in their place may not accurately reflect true nutrient intake. In this study iron deficiency was defined using criteria from the CDC. Studies examining iron status use different indicators of iron status. Comparison of dietary factors influence on iron status between studies is difficult due to the variety of iron status indicators used. Infants and toddlers diet's are very different. Breast milk or iron-fortified formula may play a factor in iron status in infants resulting in difficulty in comparing infant and toddler diets. 


\section{CHAPTER 6}

\section{CONCLUSION}

This study showed that some children's diets are not following the dietary recommendations to prevent childhood iron deficiency as issued by the $\mathrm{CDC}$, Maternal and Child Health Bureau, and the American Academy of Family Physicians to prevent iron deficiency (USDHHS, 1998; Story, 2002; Kazal, 2002). Twenty five percent of the WIC participants 6-24 months were found to be iron deficient with a majority of incidences among 13-24 month olds. The results of this study suggest that there is a relationship between the consumption of one age-appropriate serving per day of an infant or adult iron-fortified cereal and iron status in WIC participants from 8 counties in West Virginia, ages 6-24 months. The results also suggest that there is a relationship between dietary calcium intake and iron status. In addition, there is a relationship between ironfortified cereal consumption, calcium consumption and iron status when examined all together. Serum ferritin was influenced by calcium. The results indicating a relationship between meat, fish or poultry intake and serum ferritin in all children and 6-12 month olds is questionable due to possible influence of formula or breast milk on serum ferritin. All children met and exceeded nutrient recommendations for calcium and vitamin $\mathrm{C}$. Children ages 13-24 months in this population were found to consume inadequate amounts of iron per day. Iron intake in this study did not show a significant effect on iron status, but further investigations would be helpful to identify strategies to help children meet the DRI for iron intake in children 13-24 months.

Further studies could include examination of dietary patterns influence on iron status in 13-24 month old children separated into two age groups, 13-18 months and 19- 
24 months. This would give further information on the influence of a toddler's diet when transitioning from formula or breast milk to table foods. Other studies could examine the relationship between total dietary calcium intake and milk calcium intake and their influence on iron status. In conclusion, because of the adverse, irreversible effects of persisting iron deficiency on young children, iron deficiency should be prevented in all children. Further investigations could identify dietary strategies to accomplish this goal. 


\section{REFERENCES}

Allen LH, Ahluwalia N. (1997). Improving iron status through diet: The application of knowledge concerning dietary iron bioavailability in human populations. http://www.mstproject.org/toc.htm.

Ames, S.K., Gotham, B.M., \& Abrams, S.A. (1999). Effects of high compared with low calcium intake on calcium absorption and incorporation of iron by red blood cells in small children. American Journal of Clinical Nutrition. 70:44-48.

Australian Iron Status Advisory Board, http://www.ironpanel.org.au/

Boutry, M., \& Needleman, R. (1996). Use of diet history in the screening of iron deficiency. Pediatrics. 98: 1138-1142.

Brussaard, J.H., Brants, H.A., Bouman, M., \& Lowik, M.R. (1997). Iron intake and iron status among adults in the Netherlands. European Journal of Clinical Nutrition. 51(Suppl):S51-8.

Cowin, I., Emond, A., \& Emmett, P. (2001). Association between composition of the diet and haemoglobin and ferritin levels in 18-month-old children. European Journal of Clinical Nutrition. 55:278-86.

Couper RTL, Karen NS. (2001). Iron deficiency in children: food for thought. eMedical Journal of Australia. 174:162-163. URL: http://www.mja.com.au.

Dallman P.R. (1990). Iron. In E.E. Zeigler \& L.J. Filler, (ed.), Present Knowledge in Nutrition. Washington, D.C.: ILSI Press.

Duggan, M.B., Steel, G., Elwys, G, Harbottle, L., \& Noble C. (1991). Iron status, energy intake, and nutritional status of healthy young Asian children. Archives of Disease in Childhood. 66:1386-1389.

Eden, A.N., \& Mir, M.A. (1997). Iron deficiency in 1-to 3-year old children. Archives of Pediatric and Adolescent Medicine. 151:986-988.

Englemann M.D., Davidson, L., Sandstrom, B., Walezyk, T., Hurrell, R.F., \& Michaelsen, K.F. (1998). The influence of meat on non-heme iron absorption in infants. Pediatric Research. 43: 768-73.

Fernandez-Ballart, J., Domenech-Massons, J.M., Salas, J., Arija, V., \& MartinHenneberg, C. (1992). The influence of nutrient intake on the biochemical parameters of iron status in a healthy paediatric Mediterranean population. European Journal of Clinical Nutrition. 46:143-149. 
Freire, W.B. (1997). Strategies of the Pan American Health Organization/World for the control of iron deficiency in Latin America. Nutrition Reviews. 55: 183-188.

Food and Nutrition Board. Dietary Reference Index: Applications in dietary assessment. National Academy Press, Washington DC, www.nap.edu

Gibson, S.A. (1999). Iron intake and iron status of preschool children: associations with breakfast cereals, vitamin C and meat. Public Health Nutrition. 2:521-8.

Gleerup A., Rossander-Hulthen L., Gramatkovski E., \& Hallberg L. (1995). Iron absorption from the whole diet: comparison of the effect of two different distributions of daily calcium intake. American Journal of Clinical Nutrition. 61:97-104.

Groff, J.L., Gropper, S.S., \& Hunt, S.M. (1995). Advanced Nutrition and Human Metabolism. St. Paul, MN: West publishing Company.

Guthrie, J.F. (1996). Current issues related to iron status: Implications for nutrition education and policy. Family Economics \& Nutrition Review. 9: 2-18.

Hallberg, L. (1983). Iron requirements and bioavailability of dietary iron. Experientia Suppl. 44:223-244.

Hallberg, L., Brune, M., \& Rossander-Hulthen, L. (1987). Is there a physiological role of vitamin C in iron absorption? Ann NY Acad Sci. 498: 324-332.

Hallberg, L., Brune, M., \& Rossander, L. (1989). The role of vitamin C in iron absorption. International Journal for Vitamin and Nutrition Research Supplements. 30:103-108.

Haroon, S., \& Pettifor, J.M. (2001). Iron deficiency and impaired child development. British Medical Journal. 323:1377-1378.

Heath, A.L., Skeaff, C.M., O’Brien, S.M., Williams, S.M., \& Gibson. (2001). Can dietary treatment of non-anemic iron deficiency improve iron status? Journal of the American College of Nutrition. 20:477-484.

Heath-Dagger, A.L., \& Fairweather-Tait, S.J. (2002). Clinical implications of changes in the modern diet: iron intake, absorption and status. Best Practice and Research. Clinical Haematology. 15:225-41.

Hunt J.R., \& Roughead Z.K. (2000). Adaptation of iron absorption in men consuming diets with high or low iron bioavailabilty. American Journal of Clinical Nutrition. 71: 94-102. 
Hurrell, R.F. (1997). Preventing iron deficiency through food fortification. Nutrition Review. 55: 210-222.

Institute of Medicine. (1998). Dietary Reference Intakes for Calcium, Phosphorus, Magnesium, Vitamin D, and Fluoride. Washington, D.C.: National Academy Press.

Institute of Medicine. (2000). Dietary Reference Intakes for Vitamin C, Vitamin E, Selenium and Carotenoids. Washington, D.C.: National Academy Press.

Institute of Medicine. (2002). Dietary Reference Intakes for Vitamin A, Vitamin K, Arsenic, Boron, Chromium, Copper, Iodine, Iron, Managnese, Molybdenum, Nickel, Silicon, Vanadium, and Zinc. Washington, D.C.: National Academy Press.

Lee G.R., Bithell T.C., Foerster J., Athens J.W., \& Lukens J.N. (1993) Wintrobe's clinical hematology. $9^{\text {th }}$ ed. Vol. 1. Malvern, Pennsylvania:Lea \& Feiger.

Looker, A.C., Dallman, P.R., Carroll, M.D., Gunter, E.W., \& Johnson, C.L. (1997). Prevalence of iron deficiency in the United States. Journal of American Medical Association. 277: 973-976.

Lynch, S.R., Cook, J.D. (1980). Interaction of vitamin C and iron. Ann NY Acad Sci. 355:32-44.

Kapur D., Agarwal K.N., \& Agarwal D.K. (2002). Nutritional anemia and its control. Indian Journal of Pediatrics. 69:607-16.

Kazal, L.A. (2002). Prevention of iron deficiency in infants and toddlers. American Family Physician. 66:1217-1224.

Kleinman, R.E. (1998). Pediatric Nutrition Handbook, $4^{\text {th }}$ ed. Elk Grove Village, Illinois: American Academy of Pediatrics.

Mazza J.J. (2002). Manual of Clinical Hematology, $3^{\text {rd }}$ ed. Philadelphia: Lippincot Williams \& Wilkins.

Miller D.R., \& Baehner R.L. Blood Diseases of Infancy and Childhood. $7^{\text {th }}$ ed. St Louis, Illinois: Mosby-Year Book, Inc, 1995.

Miller, V., Swaney, S., \& Deinard. A. (1985). Impact of the WIC program on the iron status of infants. Pediatrics. 75:100-105.

Mira, M., Alperstein, G., Karr, M., Ranmuthugala, G., Causer, J., Niec, A., \& Lilburne. (1996). Haem iron intake in 12-36 month old children depleted in iron: casecontrol study. British Medical Journal. 312:881-3. 
National Research Council. (1989). Recommended Dietary Allowances (10 $0^{\text {th }} \mathrm{ed}$.). Washington, D.C.: National Academy Press.

Oliveira, V., \& Gundersen, C. (2001). WIC increases the nutrient intake of children. Food Review. 24:27-31.

Oski F.A. (1993). Iron deficiency in infancy and childhood. The New England Journal of Medicine. 329: 190-193.

Oti-Boateng, P., Seshadri, R., Petrick, S., Gibson, R.A., \& Simmer, K. (1998). Iron status and dietary iron intake of 6-24 month old children in Adelaide. Journal of Paediatric Child Health. 34:250-253.

Owen, A.L., \& Owen, G.M. (1997). Twenty years of WIC: a review of some effects of the program. Journal of the American Dietetic Association. 97:777-82.

Ramakrishnan, U., Frith-Terhune, A., Cogswell, M., \& Khan, L.K. (2002). Dietary intake does not account for differences in low iron stores among Mexican American and Non-Hispanic White women: Third National Health and Nutrition Examination Survey, 1988-1994. Journal of Nutrition. 132:996-1001.

Soh, P., Ferguson, E.L., McKenzie, J.E., Skeaff, S., Parnell, W., \& Gibson, R.S. (2002). Dietary intakes of 6-24 month old urban South Island New Zealand children in relation to biochemical iron status. Public Health Nutrition. 5:339-346.

Spodaryk, K. (1999). Disparity between dietary iron intake and iron status of children aged 10-12 years. Archives of Physiology and Biochemistry. 107:361-6.

Story M, Holt K, Denise S. Bright Futures in Practice: Nutrition. Second Edition. 2002

Thane, C.W., Walmsley, C.M., Bates, C.J., Prentice, A., \& Cole, T.J. (2000). Risk factors for poor iron status in British toddlers: further analysis of data from the National Dietary and Nutrition Survey of children aged 1.5-4.5 years. Public Health Nutrition. 3:433-440.

Tilkian S.M., Conover M.B., \& Tilkian A.G. (1995). Clinical \& Nursing Implications of Laboratory Tests. St. Louis, Missouri: Mosby-Year Book, Inc.

Walter, T., De Andraca, I., Chadud, P., \& Perales, C.G. (1989). Iron-deficiency anemia: adverse effects on infant psychomotor development. Pediatrics. 84:7-14.

Washington D.C., International Life Sciences Institute. (1998). International Nutrition Anemia Consultative Group, WHO and UNICEF. Guidelines for the use of iron supplements to prevent and treat iron-deficiency anemia. http://www.1uphealth.com/alternative-medicine/iron.html 
West Virginia Department of Health and Human Resources Bureau for Public health. (1997). West Virginia pediatric nutrition surveillance system 1997 summary report.

United States Department of Agriculture, Food and Nutrition Service. (2000). Child and Adult Care Food Program (CACFP) infant and toddler meal guidelines. http://www.nde.state.ne.us/NS/cacfp/feeding_infants.pdf

United States Department of Agriculture. (2000). Meal Guidelines: Food and Nutrition Information Center and University of Maryland in Collaboration with USDA Food and Nutrition Service. www.nal.usda.gov/childcare/Cacfp/index.html.

US Department of Health and Human Services. (1998). Recommendations to prevent and control iron deficiency in the Untied States. Morbidity and Mortality Weekly Report. 47:1-29.

US Department of Health and Human Services. (2000). Healthy People 2010: Washington, DC. DHHS.

United States Department of Food and Nutrition Service. (2001). Feeding infants: A guide for use in child nutrition programs. FNS-258.

http://www.nde.state.ne.us/NS/cacfp/feeding_infants.pdf 
APPENDICES 
APPENDIX A 


\section{DATA COLLECTION FORM}

Date

Patient Name

Subject Number

Date of Birth

Gender

Weight (lbs)

or

kg

Length (cm)

or

$\mathrm{cm}$

Weight for Length

Birth/Delivery Status:

Pre-Term

$<37$ weeks
Full-Term

40 weeks

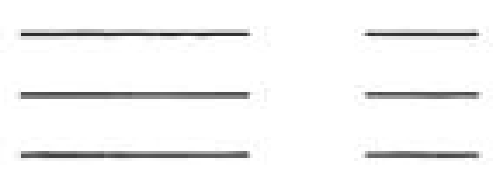

Post-Term

$>42$ weeks

Length of Gestation

Length at Birth $(\mathrm{cm})$

Weight at Birth (lbs)

MEDICAL HISTORY

History of chronic illness:

Asthma

Disability

Constipation/Vomiting

yes no
yes no
yes no

\section{DISEASES}

Diabetes yes no

Kidney Disease yes no

Cancer yes no

Heart Disease yes no

Liver Disease yes no

How long ago did the child last have
a) a cough or cold
b) diarrhea
c) ear infection
d) bacterial infection requiring antibiotics

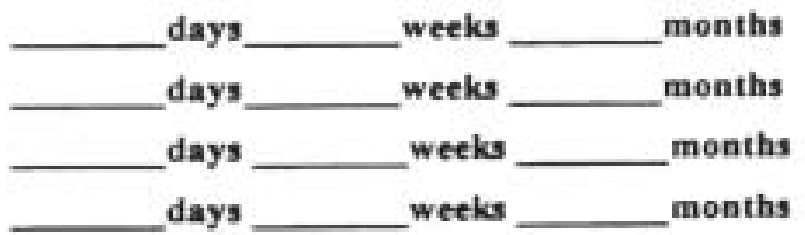


Allergies/Food Intelerances

\section{Medications}

Surgeries

Existing Nutritional Deficiencies 
APPENDIX B 


\section{DIET HISTORY}

Infant's Name

Infants' Age

1. How is your baby's appetite? Good

2. In the past two weeks, has your baby had:
Date: Infant's Weight

Fair Poor

$\begin{array}{lll}\text { Vomiting? } & \text { Yes } & \text { No } \\ \text { Diarrhea? } & \text { Yes } & \text { No } \\ \text { Constipation? } & \text { Yes } & \text { No }\end{array}$

3. Is your baby taking vitamins or minerals (including iron or fluoride)? Yes No

4. What type of water do you use? City Well Spring Cistern Other

5. Do you feed your baby with: A bottle? Yes No

A feeder? Yes No

A cup? Yes No

A spoon? Yes No

6. Do you put cereal or other foods in your baby's bottle? Yes No

7. Is food given to your baby directly from a jar? Yes No

8. How were you feeding you baby when you left the hospital? Breast Botle Both

9. Are you breastfeeding your baby now? Yes No

10. If you have stopped breastfeeding. how many weeks did you breastfeed? __ Weeks Why did you stop?

11. Does the child currently drink cow's milk?

Yes No

12. How many glasses of cow's milk does the child drink each day? (Estimat number of 8 ounce glasses of milk per day)

13. Was the mother participating in WIC before or while she was pregnant? Yes No

14. Was the mother taking prenatal vitamins?

Yes No 
APPENDIX C 


\section{Hour Recall (Script for In Person Interview)}

1. I'd like you to tell me everything (NAME) had to eat and drink all day yesterday, (DAY), from midnight to midnight. Include everything (he/she) ate and drank at home and away, including snacks, drinks, bottles, or breast milk.

\section{[WHEN RESPONDENT STOPS, ASK: Anything else?]}

Now I'm going to ask you for more detail about the foods and beverages you just listed. I will be using this notebook to find the specific questions I need to ask. When you remember anything else (NAME) ate or drank as we go along, please tell me.

When I ask about amounts, you can use these measuring guides: the cups and spoons for volume of foods; the ruler for length, width, and height of foods; and the sample baby food jars that we have with us.

2. About what time did (NAME) begin to (eat/drink) (FOOD ON LIST)? [OR CONFIRM IF RECORDED ON QUICK LIST]

3. Please tell me what you would call this occasion. [BREAKFAST, BRUNCH, LUNCH, DINNER, SUPPER, SNACK, FEEDING, OTHER (SPECIFY) - OR CONFIRM IF RECORDED ON QUICK LIST]

4. Did (NAME) have (NEXT QUICK LIST ITEM) at (TIME) with his/her (OCCASION) or was that at another time? (CONFIRM IF OBVIOUS OR RECORDED ON QUICK LIST. IF SAME TIME AND OCCASION, GO TO STEPS; IF AT ANOTHER TIME, ASK QUESTION 2)

\section{STEPS}

\begin{tabular}{|l|l|}
\hline Step 1 & $\begin{array}{l}\text { Transfer quick list food to the food/drink column. Check off food in } \\
\text { quick list as it is transferred. }\end{array}$ \\
\hline Step 2 & $\begin{array}{l}\text { Go to column } 4 \text { for food probes. Be sure to request food labels if } \\
\text { respondent cannot answer probes. }\end{array}$ \\
\hline Step 3 & Go to 5 for amount question \\
\hline Step 4 & Return to question 2 for next food recorded on quick list. \\
\hline
\end{tabular}

REVIEW

5. Now let's see if I have everything. I'd like you to try to remember anything else (NAME) ate or drank yesterday that you haven't aiready told me about, including anything (NAME) ate or drank while waiting to eat.

6. Did (NAME) have anything to eat or drink between midnight yesterday and (NAME'S) (TIME) (FIRST OCCASION)?

7. Now at (TIME) for (THIS OCCASION) (NAME) had (FOODS), did (NAME) have anything else? 
8. Did (NAME) have anything to eat or drink between (NAME'S) (TIME) (THIS

OCCASION) and (TIME) when (NAME) had (NEXT OCCASION)?

9. Repeat 7 and 8 for each occasion except last occasion. For last occasion go to 10.

10. Now at (TIME) for (LAST OCCASION) (NAME) had (FOODS), did (he/she) have anything else?

11. Did (NAME) have anything to eat or drink after (NAME'S) (TIME) (LAST

OCCASION) but before midnight last night?

12. Was the amount of food that (NAME) ate yesterday about usual, less than usual, or more than usual?

13. What is the main reason the amount (NAME) ate yesterday was (less/more) than usual?

14. Now l'd like you to think about all of the plain drinking water that (NAME) had yesterday, regardless of where (he/she) drank it. By plain drinking water, I mean tap water or any bottled water that is not carbonated, with anything added to it.

15. How many fluid ounces of plain drinking water did (NAME) drink yesterday?

16. How much of this plain drinking water came from your home? Would you day all, most, some, or none?

17. What was the main source of plain drinking water that did not come from your home? Was it tap water, water from a drinking fountain, bottled water, or something else?

18. is (NAME) on any type of formula or special diet for a health-related reason?

19. How often, if at all does (NAME) take any vitamin or mineral supplement? Would you say every day or almost every day, every so often, or not at all?

20. What types of supplements does (NAME) usually take - a multivitamin; a multivitamin with iron or other minerals; combination of specific vitamins? (list all that apply).

Interviewer Observations

Do not read these questions to the respondent.

1. Who was the main respondent for this interview? (Mother, father, sister, brother, grandparent, aunt, uncle, someone else) 
2. Who else helped in responding for this interview?

3. Did you or the respondent have difficulty with this intake interview?

4. What was the reason for this difficulty?

5. Is data retrieval necessary for daycare/baby-sitter or other caretaker? If yes, record information for follow-up phone call. 


\section{APPENDIX D}


ID Number

\section{Individual Intake Forms}

\begin{tabular}{|c|c|c|c|}
\hline $\begin{array}{c}\text { Column1 } \\
\text { Quick List of Food Items }\end{array}$ & $\checkmark$ & $\begin{array}{c}\text { Column } 2 \\
\text { Time }\end{array}$ & $\begin{array}{l}\text { Column } 3 \\
\text { Occasion }\end{array}$ \\
\hline A. & & $\begin{array}{l}\text { am } \\
\mathrm{pm}\end{array}$ & \\
\hline B. & & $\begin{array}{l}\text { am } \\
\mathrm{pm}\end{array}$ & \\
\hline C. & & $\begin{array}{l}\mathrm{am} \\
\mathrm{pm}\end{array}$ & \\
\hline D. & & $\begin{array}{l}\text { am } \\
\mathrm{pm}\end{array}$ & \\
\hline E. & & $\begin{array}{l}\text { am } \\
\mathrm{pm}\end{array}$ & \\
\hline $\mathrm{F}$. & & $\begin{array}{l}\text { am } \\
\mathrm{pm}\end{array}$ & \\
\hline G. & & $\begin{array}{l}\text { am } \\
\text { pm }\end{array}$ & \\
\hline H. & & am & \\
\hline I. & & $\begin{array}{l}\text { am } \\
\mathrm{pm}\end{array}$ & \\
\hline $\mathrm{J}$ & & $\begin{array}{l}\text { am } \\
\mathrm{pm}\end{array}$ & \\
\hline K & & $\begin{array}{l}\text { am } \\
\mathrm{pm}\end{array}$ & \\
\hline L. & & $\begin{array}{l}\text { am } \\
\text { pm }\end{array}$ & \\
\hline $\mathrm{M}$ & & $\begin{array}{l}\text { am } \\
\text { pm }\end{array}$ & \\
\hline $\mathrm{N}$. & & pm & \\
\hline 0. & & am & \\
\hline P. & & am & \\
\hline Q & & am & \\
\hline $\mathrm{R}$ & & $\begin{array}{l}\text { am } \\
\text { pm }\end{array}$ & \\
\hline S. & & $\begin{array}{l}\text { am } \\
\text { pm }\end{array}$ & \\
\hline $\mathrm{T}$. & & am & \\
\hline
\end{tabular}


ID Number

Page 2

\begin{tabular}{|c|c|c|}
\hline Food/Drink with Additions & $\begin{array}{c}\text { Column } 4 \\
\text { Description of Food/Drink } \\
\text { and Ingredient Amounts }\end{array}$ & $\begin{array}{l}\text { Column } 5 \\
\text { How much of this } \\
\text { (FOOD) did (NAME) } \\
\text { actually (eat/drink)? }\end{array}$ \\
\hline 1. & & \\
\hline 2. & & \\
\hline 3. & & \\
\hline 4. & & \\
\hline 5. & & \\
\hline 6. & & \\
\hline 7. & & \\
\hline 8. & & \\
\hline 9. & & \\
\hline 10. & & \\
\hline 11. & & \\
\hline 12. & & \\
\hline 13. & & \\
\hline 14. & & \\
\hline 15. & & \\
\hline 16. & & \\
\hline 17. & & \\
\hline 18. & & \\
\hline 19. & ' & \\
\hline 20. & & \\
\hline
\end{tabular}


12. Amount of food Usual Less More

13. Reason

15. Ounces of plain drinking water

16. Amount from home

17. Source of water outside of home

18. Special formula or diet?

19. Vitamin or minerals Daily Occasionally Not at all

20. Types of supplements (brand)

Interviewer Observations

1. Main respondent

2. Additional respondent

3. Any difficulty

4. Reason

5. Information for follow-up phone call 
APPENDIX E 


\section{Infant Meal Guidelines - Ages 0-11 Months (SEE REVERSE SIDE FOR TODDLERS)}

Source: Child and Adult Care Food Program, USDA Food and Nutrition Service Updated $9 / 25 / 00$ wew.nal usile sowichildeare/Cacfprinder huml

\section{BREAKFAST}

\begin{tabular}{|c|c|c|}
\hline Birth Through 3 Menths & 4 Through 7 Menths & 8 Through 11 Menths \\
\hline $\begin{array}{l}4-6 \text { fluid ounces of formula or } \\
\text { brenst milk }\end{array}$ & $\begin{array}{l}4-8 \text { fluid ounoes of formula or } \\
\text { breast milk }\end{array}$ & $\begin{array}{l}6-8 \text { fluid ounces of formula or } \\
\text { breast milk }{ }^{2} \text { and }\end{array}$ \\
\hline & $0-3$ thsp, infant ceren! $\left.\right|^{1 / 4}$ & $\begin{array}{l}2-4 \text { tbsp. infant cereal }\left.\right|^{1} \text { and } \\
1-4 \text { tbsp. fruit and/or vegetable }\end{array}$ \\
\hline
\end{tabular}

\section{LUNCH OR SUPPER}

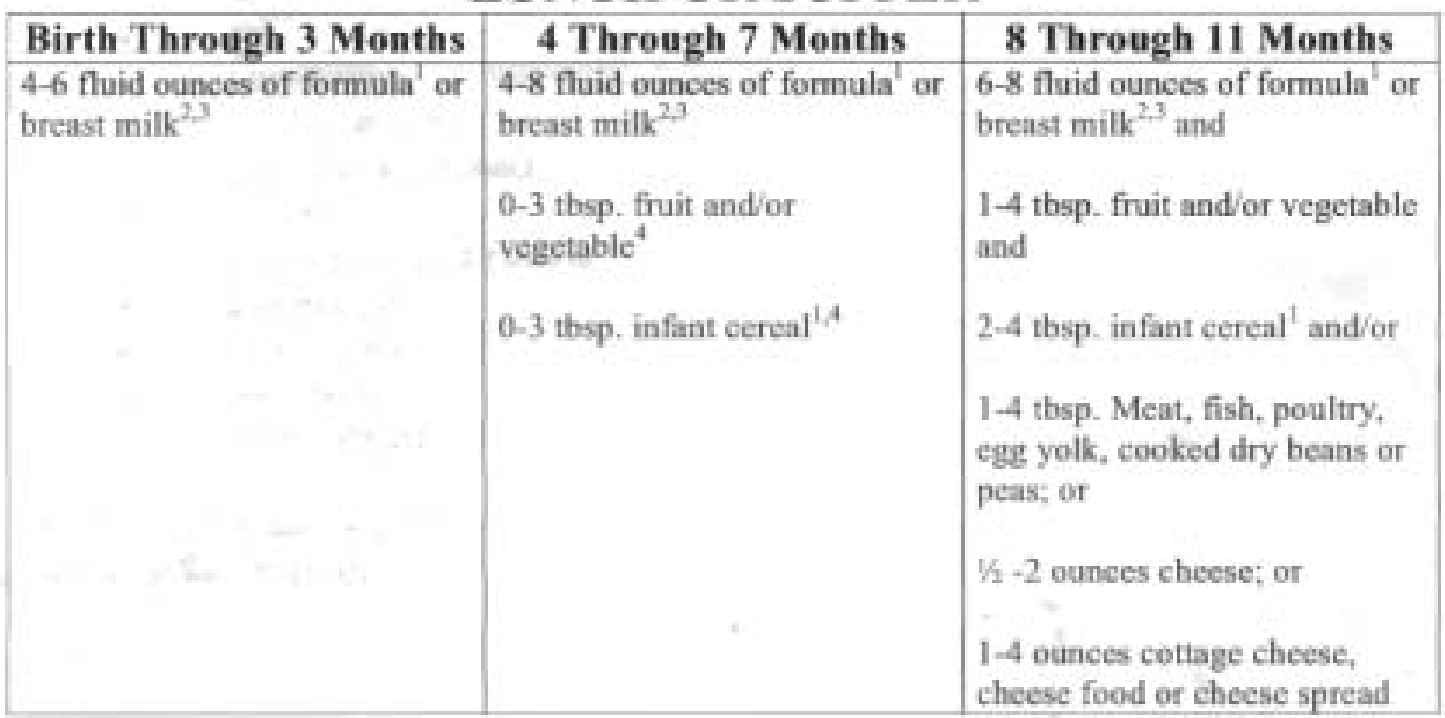

\section{SNACK}

\begin{tabular}{|c|c|c|}
\hline Birth Through 3 Months & 4 Through 7 Menths & 8 Through 11 Months \\
\hline $\begin{array}{l}\text { 4-6 fluid ounces of formula' or } \\
\text { breast milk }\end{array}$ & $\begin{array}{l}4-6 \text { fluid ounces of formula or } \\
\text { breast milk }{ }^{2,3}\end{array}$ & $\begin{array}{l}2-4 \text { fluid ounces of formula', } \\
\text { breast milk }{ }^{2,3} \text { or fruit juice } \\
0-1 / 2 \text { hread }^{4.6} \text { or } \\
0-2 \text { crackers }{ }^{46}\end{array}$ \\
\hline
\end{tabular}

\section{Footnetes}

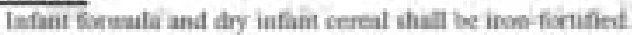

His recummended that breast will be served in place of formula from birth thomgh 11 months

Fer some breastied infints who regulinhy consume best than the minimum amauni of hreast milik per foctine, servine of less than

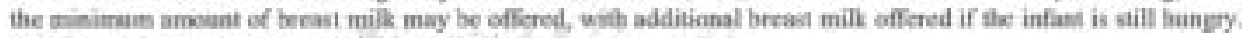

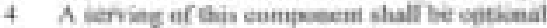

5 Fruit juice shall be full-strength.

6 Breat and beead altemases shall be made trom whok gnis er enriched axal or flour. 


\section{Toddler Meal Guidelines - Ages 1-2}

Source: Child and Adult Care Food Program, USDA Food and Nutrition Service Updared 9/25/00 www.nal.usda.osvichildcareatCacferindex htm

\section{BREAKFAST}

\begin{tabular}{|c|c|}
\hline Food Components & Ages 1-2 \\
\hline 1 serving milk flaid milk.......................... & Y cup \\
\hline I serving fruit/vegetable juice', fnit andior vegetable. & 1/ cup. \\
\hline $\begin{array}{l}\text { I serving grains/hread" } \\
\text { hrosd or. }\end{array}$ & Yas slice. \\
\hline Combread, biscail, roll or maffin, or & 1/s serving \\
\hline Cold dry cereal or......................... & 1/. cup.... \\
\hline Hot cooked cereal of .................... & Yap cu... \\
\hline 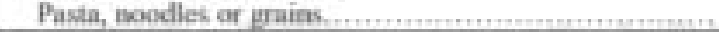 & \% cup ................ \\
\hline
\end{tabular}

\section{LUNCH OR SUPPER}

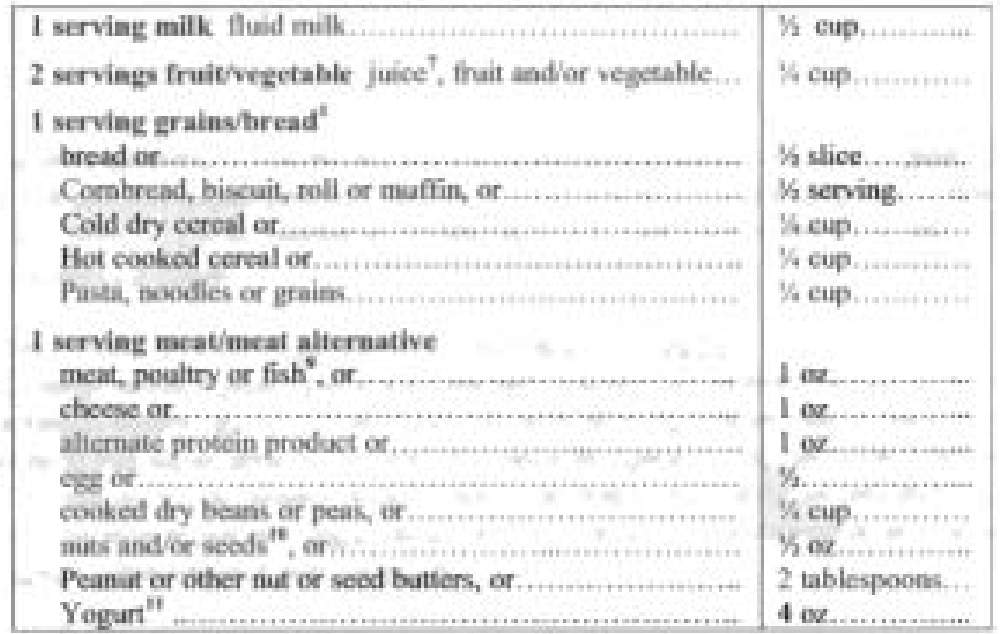

SNACK: Choose 2 of the 4 components

\begin{tabular}{|c|c|}
\hline I serving milk fluid milk. & 1/ cup \\
\hline I serving fruit/vegetable juice', fruit and/ar vegetable... & 1/sup. \\
\hline $\begin{array}{l}1 \text { serviag erainsfhread" } \\
\text { bread or................ }\end{array}$ & $1 / 2$ slice. \\
\hline 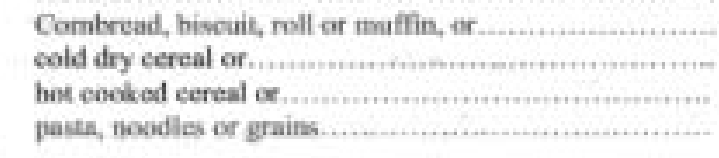 & 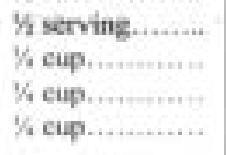 \\
\hline 1 serviag meat/meat alternative & $1=0$ \\
\hline altermate & 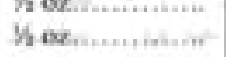 \\
\hline cheese of & Koz \\
\hline ege or & $1 / 8$ cup.............. \\
\hline $\begin{array}{l}\text { coolied dry beans or poas, or } \\
\text { nuts and/ar seeds, or. }\end{array}$ & $\begin{array}{l}1 / 8 \text { cup } \\
1 / 2 \text { or } \ldots \ldots+\cdots\end{array}$ \\
\hline $\begin{array}{l}\text { peanut or other nut or soed buiten, or } \\
\text { yegurt }{ }^{11}\end{array}$ & $\begin{array}{l}\text { I tablespoon. } \\
20 \mathrm{x}\end{array}$ \\
\hline
\end{tabular}

\section{Foetnetes}

7 Fruit or vegsable juice muit be full-strengh. Juice cannot be comated as the second snark item if the other snack, isem is mulk.

8. Ereads and grains must he made from whole-grain or enricbed meal or flour. Cerral must be whole-grain ar enrichod or fortified.

9 A serving consists of the edible pontion af eooked lian moat ar poeltry ar finh

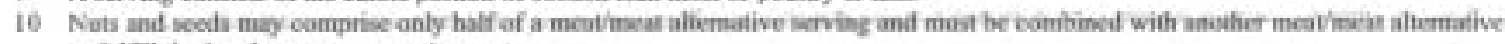
bs fulfill the kath ar supper requirement.

II Yogurt may be plain or flavored, unsweclened of iwectened. 
APPENDIX F 
Common Foods Consumed by Study Participants

\begin{tabular}{|c|c|c|c|c|c|c|}
\hline Breads \& Cereal & Fruits & Vegetables & $\begin{array}{l}\text { Milk \& } \\
\text { Dairy }\end{array}$ & Protein & Meat & Fats \& Sweets \\
\hline
\end{tabular}




\section{APPENDIX G}




\section{Data Coding Questions}

1. Is the child consuming one serving of an iron-fortified adult or baby cereal at least 1 time per day?

2. Is the child consuming one serving of meat, poultry or fish each day?

3. Is the child consuming one serving of a fruit, vegetable or juice with one meal per day?

4. Is the child consuming $>24$ ounces of milk per day?

5. Is the child taking a multi-vitamin supplement each day? 
APPENDIX H 


\section{Prevention Recommendations}

\begin{tabular}{|c|c|c|c|}
\hline Dietary Factor & $C D C$ & Bright Futures & $\begin{array}{l}\text { American Academy of } \\
\text { Family Physicians }\end{array}$ \\
\hline Cereal Intake & $\begin{array}{l}\text { At 4-6 months or when the } \\
\text { extrusion reflex disappears, } \\
\text { recommend that infants be } \\
\text { introduced to plain, iron } \\
\text { fortified infant cereal. } 2 \text { or } \\
\text { more servings per day can } \\
\text { meet an infant's requirement } \\
\text { for iron at this age }\end{array}$ & $\begin{array}{l}\text { Consume highly fortified } \\
\text { breakfast cereals that } \\
\text { can improve iron } \\
\text { intake }\end{array}$ & $\begin{array}{l}\text { Use cereals fortified with iron } \\
\text { instead of more } \\
\text { advertised cereals }\end{array}$ \\
\hline Meat/Fish/Poultry & $\begin{array}{c}\text { Introduce plain, pureed meats }>6 \\
\text { months or when infant } \\
\text { developmentally ready }\end{array}$ & $\begin{array}{l}\text { Increase consumption of lean } \\
\text { meat, fish and poultry. }\end{array}$ & $\begin{array}{l}\text { Consume a diversified diet } \\
\text { rich in iron sources }\end{array}$ \\
\hline Cow's Milk & $\begin{array}{l}\text { Children 1-5 years consume no } \\
\text { more than } 24 \text { oz cow's milk, } \\
\text { goat's milk, or soy milk } \\
\text { each day. }\end{array}$ & & $\begin{array}{l}\text { Limit cow's milk to less than } \\
24 \mathrm{oz} \text { per day }\end{array}$ \\
\hline Fruit/Vegetable/Juice & $\begin{array}{l}\text { By } 6 \text { months, encourage one } \\
\text { feeding per day of foods rich } \\
\text { in vitamin C (Fruits, } \\
\text { vegetables or juice) to } \\
\text { improve iron absorption, } \\
\text { preferably with meals }\end{array}$ & $\begin{array}{l}\text { Include sources of vitamin C } \\
\text { with meals }\end{array}$ & $\begin{array}{c}\text { Consume a diversified diet } \\
\text { rich in vitamin } C\end{array}$ \\
\hline Multivitamin & & & $\begin{array}{l}\text { Provide a daily iron-fortified } \\
\text { vitamin }\end{array}$ \\
\hline
\end{tabular}


APPENDIX I 


\section{Serving Sizes}

\begin{tabular}{|c|c|c|c|}
\hline Food Group & 6-12 Months & $\begin{array}{c}1-2 \\
\text { years }\end{array}$ & Not Acceptable \\
\hline Meat/Poultry/Fish & $>$ 1Tbs plain meat & $>1 \mathrm{oz}$ & $\begin{array}{l}\text { Meat combination baby food } \\
\text { dinners a , pepperoni, canned } \\
\text { chicken noodle soup, }\end{array}$ \\
\hline Fruit & $>1$ Tbsp plain fruit ${ }^{b}$ & $1 / 4$ cup & $\begin{array}{l}\text { Baby food desserts, baby food } \\
\text { puddings, jelly }\end{array}$ \\
\hline Vegetable & $\begin{array}{l}>1 \text { Tbsp plain } \\
\text { vegetable }^{\mathrm{b}}\end{array}$ & $1 / 4$ cup & $\begin{array}{l}\text { Combination meat and vegetable } \\
\text { dinners }\end{array}$ \\
\hline Juice & $\begin{array}{l}>2 \text { oz juice (Full- } \\
\text { Strength) }\end{array}$ & $1 / 4$ cup & $\begin{array}{l}\text { Kool-Aid, fruit drink, punch, } \\
\text { soda, tea, juices not containing } \\
100 \% \text { fruit juice }\end{array}$ \\
\hline $\begin{array}{l}\text { Iron-Fortified } \\
\text { Cereals }\end{array}$ & $\begin{array}{l}>1 \text { Tbsp baby } \\
\text { cereal }\end{array}$ & $1 / 4$ cup & $\begin{array}{l}\text { Fruit Loops, Lucky Charms, } \\
\text { Cocoa Wheats, Fruity Pebbles, } \\
\text { Apple Jacks }\end{array}$ \\
\hline
\end{tabular}

${ }^{a}$ Commercially prepared baby food combination dinners- the amounts of the various food components in the dinners are difficult to determine. Information on the exact percentages of ingredients is proprietary and thus not available to the public. Give the small percentage of meat required to be in these foods, these dinners may not be a primary source of meat/meat alternative for a baby. Theses dinners generally have less nutritional value by weight than single-ingredient meats and vegetables or fruit mixed together (USDFNS, 2001).

${ }^{\mathrm{b}}$ Only plain fruit or vegetable prepared baby foods were accepted as a fruit or vegetable source. Plain commercial baby food vegetables and fruits generally contain more nutrients ounce for ounce, do not usually contain concentrated sweeteners or salt (USDFNS, 2001).

${ }^{\mathrm{c}}$ Only $100 \%$ juices accepted as juice source. Juices that are not $100 \%$ juice often contain added sugar (USDFNS, 2001). Although some fruit drinks contain vitamin C, only $100 \%$ juices were accepted. Vitamin C intake from these drinks was accounted for in the nutrient analysis. 
APPENDIX J 


\section{Summary:Recommendations}

Table: Summary of dietary recommendations, children not consuming, iron status \& serum ferritin

\begin{tabular}{|c|c|c|c|}
\hline & 6-12 Months $(\mathrm{n}=18)$ & 13-24 Months ( $\mathrm{n}=32)$ & $\operatorname{ALL}(=50)$ \\
\hline $\begin{array}{l}\text { Cereal } \\
\text { Iron Status } \\
\text { Serrum Ferritin }\end{array}$ & $\begin{array}{l}\text { Not Consuming-4 } \\
\text { ns } \\
\text { ns }\end{array}$ & $\begin{array}{l}\text { Not Consuming-14 } \\
\text { Significant } \\
\text { ns }\end{array}$ & $\begin{array}{l}\text { Not Consuming-18 } \\
\text { Significant } \\
\text { ns }\end{array}$ \\
\hline $\begin{array}{l}\text { Meat/Fish/Poultry } \\
\text { Iron Status } \\
\text { Serrum Ferritin }\end{array}$ & $\begin{array}{l}\text { Not Consuming- } 16 \\
\text { ns } \\
\text { ns }\end{array}$ & $\begin{array}{l}\text { Not Consuming- } 3 \\
\text { ns } \\
\text { ns }\end{array}$ & $\begin{array}{l}\text { Not Consuming-19 } \\
\text { ns } \\
\sqrt{\text { Significant }}\end{array}$ \\
\hline $\begin{array}{l}\text { Fruit/Veg/Juice } \\
\text { Iron Status } \\
\text { Serrum Ferritin }\end{array}$ & $\begin{array}{l}\text { Not Consuming-0 } \\
\text { ns } \\
\text { ns }\end{array}$ & $\begin{array}{l}\text { Not Consuming- } 2 \\
\text { ns } \\
\text { ns }\end{array}$ & $\begin{array}{l}\text { Not Consuming-2 } \\
\text { ns } \\
\text { ns }\end{array}$ \\
\hline $\begin{array}{c}\text { Milk }<\mathbf{2 4} \text { Ounces } \\
\text { Iron Status } \\
\text { Serrum Ferritin }\end{array}$ & $\begin{array}{l}\text { Not Consuming- } 2 \\
\text { ns } \\
\sqrt{\text { Approached Significance }}\end{array}$ & $\begin{array}{l}\text { Not Consuming- } 6 \\
\text { ns } \\
\text { ns }\end{array}$ & $\begin{array}{l}\text { Not Consuming- } 8 \\
\text { ns } \\
\sqrt{\text { Approached Significance }}\end{array}$ \\
\hline $\begin{array}{l}\text { Multivitamin } \\
\text { Iron Status } \\
\text { Serrum Ferritin }\end{array}$ & $\begin{array}{l}\text { Not Consuming- } 15 \\
\text { ns } \\
\text { ns }\end{array}$ & $\begin{array}{l}\text { Not Consuming-24 } \\
\text { ns } \\
\text { ns }\end{array}$ & $\begin{array}{l}\text { Not Consuming-39 } \\
\text { ns } \\
\text { ns }\end{array}$ \\
\hline
\end{tabular}

$\sqrt{ }=$ significant for serum ferritin $\quad$ ns=not significant 
APPENDIX K 


\section{Summary: Nutrient Intake}

Table: Summary nutrient intake, iron status and serum ferritin

\begin{tabular}{|c|c|c|c|}
\hline & 6-12 Months & 13-24 Months & ALL \\
\hline $\begin{array}{l}\text { Iron (mg/day) } \\
\text { Iron Status } \\
\text { Serrum Ferritin }\end{array}$ & $\begin{array}{l}\mathbf{1 5 . 3} \pm \mathbf{5 . 8 3} \\
(D R I / 1 \mathrm{mg} / \text { day }) \\
\mathrm{ns} \\
\mathrm{ns}\end{array}$ & $\begin{array}{l}\mathbf{4 . 9} \pm \mathbf{2 . 9 2} \\
(D R I 7 m g / d a y) \\
\text { ns } \\
\text { ns }\end{array}$ & $\begin{array}{l}12.0 \pm 5.80 \\
\text { ns } \\
\text { ns }\end{array}$ \\
\hline $\begin{array}{l}\text { Vitamin C (mg/day) } \\
\text { Iron Status } \\
\text { Serrum Ferritin }\end{array}$ & $\begin{array}{l}\mathbf{1 3 4 . 5} \pm \mathbf{5 8 . 4 3} \\
\text { (DRI 50 mg/day) } \\
\mathrm{ns} \\
\mathrm{ns}\end{array}$ & $\begin{array}{l}103.0 \pm 58.41 \\
(D R I \quad 15 \mathrm{mg} / \text { day }) \\
\mathrm{ns} \\
\mathrm{ns}\end{array}$ & $\begin{array}{l}114.5 \pm 59.81 \\
\text { ns } \\
\text { ns }\end{array}$ \\
\hline $\begin{array}{l}\text { Calcium (mg/day) } \\
\text { Iron Status } \\
\text { Serrum Ferritin }\end{array}$ & $\begin{array}{l}602.0 \pm 216.63 \\
(D R I 270 \mathrm{mg} / \text { day }) \\
\text { ns } \\
\sqrt{\text { Significant }}\end{array}$ & $\begin{array}{l}939.7 \pm 311.2 \\
(\text { DRI } 500 \mathrm{mg} / \text { day) } \\
\text { ns } \\
\sqrt{\text { Significant }}\end{array}$ & $\begin{array}{l}813.0 \pm 322.5 \\
\begin{array}{l}\text { Significant } \\
\sqrt{\text { Significant }}\end{array}\end{array}$ \\
\hline
\end{tabular}

$\sqrt{ }=$ significant for serum ferritin $\quad$ ns=not significant 
APPENDIX L 


\section{Literature Review Summary of Related Study Results}

\begin{tabular}{|c|c|c|c|c|c|c|c|}
\hline & Cereal & Meat & Fruit & Milk & Iron & Vitamin $C$ & Calcium \\
\hline $\begin{array}{l}\text { Cowin et al. } \\
\text { (2001) } \\
\text { Subjects: } \\
\quad(18 \text { month) } \\
\text { Iron Indicator: } \\
\quad \text { SF * }\end{array}$ & & $\begin{array}{l}\text { No meat intake, } \\
\text { lower Hg }\end{array}$ & & $\begin{array}{l}\text { Negative } \\
\text { association with SF }\end{array}$ & $\begin{array}{l}\text { Positive association } \\
\text { w/ Hg }\end{array}$ & & $\begin{array}{l}\text { Negative } \\
\text { association. } \\
\text { (4-5\% drop in SF } \\
\text { w/ 100mg } \uparrow \\
\text { calcium) }\end{array}$ \\
\hline $\begin{array}{l}\text { Thane et al. (2000) } \\
\text { Subjects: } \\
1.5-4.5 \text { years } \\
\text { Iron Indicator: } \\
\text { SF- }<10 u g\end{array}$ & & $\begin{array}{l}\text { Positive association } \\
\text { with SF }\end{array}$ & $\begin{array}{l}\text { Positive association } \\
\text { with SF }\end{array}$ & $\begin{array}{l}\text { Negative } \\
\text { association with } \\
\text { SF. } \\
\text { (With } \uparrow \text { milk and } \\
\uparrow \text { meat, serum }\end{array}$ & $\begin{array}{l}\text { No Association w/ } \\
\text { SF }\end{array}$ & & \\
\hline $\begin{array}{l}\text { Gibson (1999) } \\
\text { Subjects: } \\
1.5-4.5 \mathrm{yr} \\
\text { Iron Indicator: } \\
\text { SF- }<10 \mathrm{ug}\end{array}$ & $\begin{array}{l}\text { No association with } \\
\text { iron status } \\
(\mathrm{p}=0.067) . \text { With } \\
\text { increased cereal } \\
\text { intake, increased } \\
\text { iron intake. }\end{array}$ & $\begin{array}{l}\text { With } \uparrow \text { vit } \mathrm{C} \text {, } \\
\uparrow \text { cereal \& } \uparrow \text { meat } \\
\text { intake, hemoglobin } \\
\text { was higher }\end{array}$ & & & & $\begin{array}{l}\text { With } \uparrow \text { vit } C \text {, } \\
\uparrow \text { cereal \& } \uparrow \text { meat } \\
\text { intake, hemoglobin } \\
\text { was higher }\end{array}$ & \\
\hline $\begin{array}{l}\text { Soh et al. (2002) } \\
\text { Subjects: } \\
\text { 6-24 months } \\
\text { Iron Indicator: } \\
\text { SF- }<2 \text { 20ug }\end{array}$ & & No significance & No significance & $\begin{array}{l}\text { Significant for } \\
\text { toddlers }\end{array}$ & $\begin{array}{l}\text { Positive association } \\
\text { with SF }\end{array}$ & Positive w/SF & $\begin{array}{l}\text { Negative } \\
\text { association with } \\
\text { SF }\end{array}$ \\
\hline $\begin{array}{l}\text { Oti-Boateng et al. } \\
\text { (1998) } \\
\text { Subjects: } \\
6-24 \text { months } \\
\text { Iron Indicator: } \\
\mathrm{Hg}>110 \\
\mathrm{SF}<15 \mathrm{ug} \\
\mathrm{SI}<8 \text { umol } \\
\mathrm{TS}<12 \%\end{array}$ & & & & $\begin{array}{l}\text { Negative } \\
\text { association with } \\
\text { iron status }\end{array}$ & & & \\
\hline
\end{tabular}




\section{VITA}

NAME: Marci Stayner Cannon

\section{EDUCATION:}

May $2003 \quad$ Masters of Science: Human Nutrition and Foods

West Virginia University, Morgantown, WV

June 1997 Bachelors of Science: Nutrition and Food Science, Dietetics

Utah State University, Logan, UT

PROFESSIONAL EXPERIENCE:

Jun 01-May 03 Center for Excellence in Disablities, Morgantown, WV: Dietitian

Summer 2002 Diabetes Camp Kno-Koma, Wheeling, WV: Volunteer Dietitian

Nov 00-Jun 01 Magic Valley Medical Center, Twin Falls, ID_: Clinical Dietitian

Jan 00-Nov $00 \quad$ WIC, Salt Lake City, UT: Women, Infant, Children's Dietitian

May 97-Dec 99 Geneva, Switzerland: Volunteer Missionary

Sep 97-Apr 97 LDS Hospital, Salt Lake City, UT: Administrative Dietitian

\section{PERSONAL INTERESTS:}

cooking, traveling, ballroom dancing, singing, watching musicals, learning the piano, cross-country skiing 